\title{
Werken en leren in Nederland
}

Citation for published version (APA):

Borghans, L., Fouarge, D., de Grip, A., \& van Thor, J. A. F. (2014). Werken en leren in Nederland. ROA. ROA Reports No. 003 https://doi.org/10.26481/umarep.2014003

Document status and date:

Published: 01/01/2014

DOI:

10.26481/umarep.2014003

Document Version:

Publisher's PDF, also known as Version of record

\section{Please check the document version of this publication:}

- A submitted manuscript is the version of the article upon submission and before peer-review. There can be important differences between the submitted version and the official published version of record.

People interested in the research are advised to contact the author for the final version of the publication, or visit the DOI to the publisher's website.

- The final author version and the galley proof are versions of the publication after peer review.

- The final published version features the final layout of the paper including the volume, issue and page numbers.

Link to publication

\footnotetext{
General rights rights.

- You may freely distribute the URL identifying the publication in the public portal. please follow below link for the End User Agreement:

www.umlib.nl/taverne-license

Take down policy

If you believe that this document breaches copyright please contact us at:

repository@maastrichtuniversity.nl

providing details and we will investigate your claim.
}

Copyright and moral rights for the publications made accessible in the public portal are retained by the authors and/or other copyright owners and it is a condition of accessing publications that users recognise and abide by the legal requirements associated with these

- Users may download and print one copy of any publication from the public portal for the purpose of private study or research.

- You may not further distribute the material or use it for any profit-making activity or commercial gain

If the publication is distributed under the terms of Article $25 \mathrm{fa}$ of the Dutch Copyright Act, indicated by the "Taverne" license above, 


\title{
Werken en leren in Nederland
}

\author{
Lex Borghans \\ Didier Fouarge \\ Andries de Grip \\ Jesper van Thor
}

ROA-R-2014/3 


\section{Colofon}

(C) Researchcentrum voor Onderwijs en Arbeidsmarkt (ROA). Niets uit deze uitgave mag op enige manier worden verveelvoudigd zonder voorafgaande schriftelijke toestemming van de directeur van het ROA.

\section{Researchcentrum voor Onderwijs en Arbeidsmarkt}

School of Business and Economics

Maastricht University

\section{Vormgeving}

ROA secretariaat, Maastricht

\section{Verkoop}

Researchcentrum voor Onderwijs en Arbeidsmarkt email: secretary-roa-sbe@maastrichtuniversity.nl website: www.roa.nl

ISBN: 978-90-532I-527-2 


\section{Inhoud}

Voorwoord $\quad$ v

Resumé vii

I Trends in het leren in Nederland I

I.I Ontwikkelingen in de cursusdeelname I

I.2 Ontwikkelingen in informele leren en zelfstudie II

I.3 Trends in de kennisontwikkeling $\quad$ I6

I.4 Leren, employability en mobiliteit I8

2 Formeel en informeel leren door flexwerkers 23

2.I Cursusdeelname, informeel leren en zelfstudie 23

2.2 Scholing van flexwerkers in tijd en geld 28

2.3 Motieven van flexwerkers om te leren 30

2.4 Flexwerkers en leerzame taken op het werk 33

2.5 Maken salaris en het leren op het werk flexibele banen
aantrekkelijker?

3 Formeel en informeel leren door oudere werkenden 39

3.I Ontwikkeling in het leren van ouderen 40

3.2 Leren naar contractvorm en leeftijd 44

3.3 Leren, motivatie en HR-beleid 46

$\begin{array}{ll}\text { Literatuur } & 49\end{array}$

Bijlage A: ROA Levenslang Leren Enquête 53

Bijlage B: Formeel, informeel leren en zelfstudie naar bedrijfssector $\quad 57$

Bijlage C: Kosten van scholing en initiatief voor scholing naar contractvorm en opleidingsniveau 59

Bijlage D: Meting van motivatie, risico attitude en HR beleid 6I 



\section{Voorwoord}

In dit rapport brengen wij het formele en informele leren en de kennisontwikkeling in Nederland in kaart aan de hand van vier peilingen van de ROA Levenslang Leren Enquête voor de jaren 2004, 2007, 2010 en 2013. Aangezien het monitorgedeelte van de vragenlijst gedurende deze jaren ongewijzigd is gebleven, is het mogelijk om trends en ontwikkelingen in kaart te brengen. Hierbij gaat het om trends over het leren in Nederland alsook over factoren die dit leerproces in positieve dan wel negatieve zin beïnvloeden. De continuering van deze monitor werd mogelijk gemaakt door middel van een opdracht van het Ministerie van Sociale Zaken en Werkgelegenheid. Vanwege de specifieke beleidsmatige aandacht voor de scholingsdeelname en het informele leren van flexwerkers is in de 2013 de ROA Levenslang Leren Enquête specifiek aandacht besteed aan deze de afgelopen jaren in omvang toegenomen groep werkenden. Wij danken Maurice Doll, Toon Janssen en Max Raterink van het Ministerie van Sociale Zaken en Werkgelegenheid, en André de Moor en Geert Agteresch van het Ministerie van Onderwijs, Cultuur en Wetenschap voor hun commentaar op een eerdere versie van dit rapport. 



\section{Resumé}

Vanuit het basismodel van de menselijk kapitaal theorie zou men geneigd kunnen zijn te denken dat alle investeringen in menselijk kapitaal in het initieel onderwijs zouden moeten plaatsvinden. Immers, in dat geval is de periode waarin iemand profijt kan hebben van de gevolgde scholing het langst. Bovendien blijkt dat het volgen van scholing een zichzelf versterkend proces is en ook een positief effect heeft op het rendement van de scholing die men daarna volgt. Nobelprijswinnaar James Heckman (2000) vatte dit kernachtig samen: "Learning begets learning. Skills acquired early on make learning easier. More able people find learning easier."

Het is echter een illusie om te denken dat alle investeringen in menselijk kapitaal die vereist zijn om mensen tot hun pensioen duurzaam inzetbaar te houden, kunnen plaatsvinden voordat iemand toetreedt tot de arbeidsmarkt (De Grip 2000). Het "een leven lang leren" vervult zelfs een steeds grotere rol bij het up-to-date houden van het kennisniveau van de Nederlandse beroepsbevolking. Daarvoor zijn twee belangrijke oorzaken aan te wijzen: (I) de snelle technologische en organisatorische vernieuwingen van de productieprocessen in vrijwel alle bedrijfssectoren en (2) de verlenging van de arbeidsloopbaan vanwege de noodzaak om in een samenleving met een vergrijzende bevolking op latere leeftijd met pensioen te gaan.

Vanuit beleidsoogpunt is het van groot belang om een goed beeld te hebben van de wijze waarop het levenslang leren in Nederland gestalte krijgt, en de mate waarin bepaalde groepen participeren in de verschillende vormen van formeel en informeel leren. De opeenvolgende peilingen van de ROA Levenslang Leren Enquête (2004, 2007, 2010 en 2013) bieden de mogelijkheid hier een beeld van te geven. De belangrijkste bevindingen uit dit rapport laten zich als volgt samenvatten:

\section{Cursusdeelname blijft op peil, maar groeiende kloof tussen hoog- en laagopgeleiden}

- In 2013 gaf ruim de helft ( $53 \%)$ van de werkenden en eenvijfde $(22 \%)$ van de niet-werkenden aan in de afgelopen twee jaar een cursus of training te hebben gevolgd. Deze percentages zijn nagenoeg onveranderd gebleven ten opzichte van 2004. Het is opmerkelijk dat de economische crisis geen gevolgen heeft gehad op de scholingsdeelname van werkenden en niet-werkenden. Echter, de duur van de cursussen die werkenden hebben gevolgd is tussen 2004 en 2013 
afgenomen van gemiddeld 25 uur naar 2I uur per cursus. Deze ontwikkeling wijst er op dat de gevolgde cursussen 'lichter' van aard worden.

- 2013 is het eerste jaar waarin werkende vrouwen iets vaker aan cursussen en trainingen deelnamen dan werkende mannen. Echter, de kloof in de scholingsdeelname tussen aan de ene kant laagopgeleiden en aan de andere kant middelbaar en hoogopgeleiden is tussen 2004 en 2013 toegenomen. Ook de kloof in de duur van de cursussen is toegenomen. Deze groeiende kloof in de cursusdeelname tussen hoog- en laagopgeleiden is vanuit beleidsoptiek een mogelijke punt van zorg, omdat het zou kunnen betekenen dat laagopgeleiden het risico lopen minder goed mee te kunnen met de veranderingen die zich voordoen in hun werk.

- Hoogopgeleiden geven veel vaker (43\%) dan middelbaar en laagopgeleiden (ongeveer een kwart) aan dat zij zelf het initiatief hebben genomen om een cursus te volgen. Uit eerder onderzoek is gebleken dat persoonlijkheidskenmerken van laagopgeleiden (bijvoorbeeld examenangst) medebepalend zijn voor hun bereidheid om aan cursussen deel te nemen. Dit geeft aan dat het aanbieden van cursussen in een meer informele setting en de erkenning van elders verworven competenties (EVC) de cursusdeelname van laagopgeleiden zou kunnen stimuleren.

- $87 \%$ van alle cursussen wordt door de werkgever betaald. De in de gevolgde cursussen ontwikkelde kennis en vaardigheden zijn in de regel vooral bedrijfsof branchespecifiek. Toch verwacht $44 \%$ van de werkenden die een cursus hebben gevolgd dat de opgedane kennis ook bruikbaar zou zijn wanneer zij in een andere branche zouden gaan werken. Daarnaast geeft bijna de helft van de cursusdeelnemers aan dat ze de in de cursus opgedane kennis en vaardigheden hebben overgedragen aan hun collega's. Door dergelijke spill-overs op de werkvloer is de meerwaarde van cursussen niet alleen beperkt tot de cursusdeelnemer zelf. Dit spill-over effect heeft een positief effect op het rendement dat werkgevers hebben van de scholingsinvesteringen in hun medewerkers.

\section{Informeel leren is belangrijkste bron van nieuwe kennis}

- In 2013 blijken werkenden 35\% van hun werktijd te besteden aan werkzaamheden waarvan zij leren. Dat is aanzienlijk meer dan in de jaren daarvoor. Tussen 2004 en 2010 nam dit percentage zelfs nog af van $31 \%$ naar $28 \%$ van de werktijd. De sterke toename van het informeel leren op het werk tussen 2010 en 2013 blijkt in belangrijke mate toe te schrijven aan de toename van het leren op het werk bij middelbaar opgeleiden (+10\%-punt) en in iets mindere mate onder hoogopgeleiden (+6\%-punt). Onder lager opgeleiden blijft het percentage van de werktijd waarin men activiteiten heeft waarvan men leert sinds 2007 stabiel. Naast het informeel leren op het werk deed in $201341 \%$ van de werkenden aan zelfstudie thuis. Zij besteedden daar per maand gemiddeld ongeveer 3 uur aan. 
- Vrouwen besteden gemiddeld genomen een groter deel van hun werktijd aan informeel leren dan mannen: $37 \%$ tegen $33 \%$. Ook hoogopgeleiden besteden een groter deel van hun werktijd aan informeel leren (38\%) dan middelbaar $(35 \%)$ en laagopgeleiden (26\%). Hoewel deze kloof tussen laag- en hoogopgeleiden deels te maken heeft met verschillen in de aard van de werkzaamheden, geeft het wel aan dat laagopgeleiden, niet alleen minder leren via formele cursussen, maar ook op hun werk minder bijleren doordat zij minder uitdagende taken uitvoeren.

- Van de totale tijd die werkenden aan leeractiviteiten besteden heeft veruit het grootste deel (96\%) betrekking op het informeel leren tijdens het werk. Slechts $4 \%$ heeft betrekking op het volgen van cursussen en trainingen. Bovendien blijkt dat in de afgelopen jaren een steeds groter deel van de totale leertijd betrekking heeft op het informeel leren op het werk. Dit betekent niet dat het verhogen van de scholingsparticipatie van de werkzame bevolking een onbelangrijk beleidsdoel is. Er is immers sprake van een positieve wisselwerking tussen het formeel en informeel leren. Werkenden die een cursus of training hebben gevolgd, leren ook significant meer tijdens hun werk dan werkenden die geen training hebben gevolgd ( $+5 \%$-punt).

- Opmerkelijk is ook dat er geen verschil is in het leerrendement van formeel en informeel leren: gemiddeld genomen leren werkenden ongeveer evenveel per uur formeel leren als in een uur dat ze informeel op hun werk leren. Omdat werknemers echter veel meer uren besteden aan het leren tijdens hun werk dan aan het volgen van cursussen of trainingen, vormt het informele leren tijdens het werk voor de meeste werkenden veruit de belangrijkste bron van nieuwe kennis en vaardigheden.

\section{Meer zorgen over employability door crisis}

- Gemiddeld genomen geven werkenden in 2013 aan dat er in de twee voorafgaande jaren sprake was van een kennistoename van 7,1\%-punt. Hoewel de mate van kennisontwikkeling structureel afneemt tussen 2004 en 20I3, blijkt het niveau van de kennis en vaardigheden die werkenden nodig hebben om hun werk optimaal te kunnen uitvoeren steeds hoger te liggen. Dit zou echter het gevolg kunnen zijn van de vergrijzing van de werkzame bevolking als ook van een afnemende doorgroei naar een hoger functieniveau in de economische crisis waardoor werkenden meer ervaring opbouwen in hun huidige baan.

- In 2013 schatten werkenden de kans dat zij, als zij op dat moment hun baan kwijtraken een andere baan op een vergelijkbaar niveau zullen vinden, gemiddeld genomen op '50-50'. Werkenden schatten hun externe employability in de crisisjaren 2010 en 2013 significant lager in dan in 2007. Ook vrezen werkenden in 2013 vaker om hun baan in de komende vijf jaar te verliezen dan in de drie eerdere enquêtejaren. Deze perceptie van werkenden weerspiegelt de huidige onzekerheid die velen hebben over de ontwikkelingen op de arbeidsmarkt. Dit kan gevolgen hebben voor de vrijwillige mobiliteit tussen banen 
(men is meer honkvast in tijd van crisis) en daarmee op de algehele dynamiek op de Nederlandse arbeidsmarkt.

\section{Geen verschillen in informeel leren naar soort contract, maar meer zelfstudie door zzp'ers}

- Werkenden met een vast contract volgen significant vaker training dan flexibele arbeidskrachten en zzp'ers. De verschillen in de trainingsdeelname tussen flexwerkers en mensen met een vast contract waren in 2013 aanzienlijk. De trainingsdeelname varieert van bijna 3 op de Io werknemers met een tijdelijk contract zonder uitzicht op een vast contract tot bijna 6 op de Io werknemers met een vast contract. De cursusdeelname van werkenden met een vast contract (met of zonder flexibele kenmerken) wordt ook vaker betaald door de werkgever. Desalniettemin betalen werkgevers geregeld ook de cursussen van flexkrachten.

- Werkenden met een vast contract met flexibele kenmerken (bijvoorbeeld gedetacheerd of werkzaam via een payroll organisatie) volgden in de afgelopen twee jaar de meeste cursussen en besteedden bovendien naast de cursus significant meer tijd om het geleerde op hun werk onder de knie te krijgen. Zij blijken ook bij verschillende taken significant meer te leren dan personen met een ander type contract.

- Hoewel de verschillen in cursus deelname naar de aard van het arbeidscontract groot zijn, zijn de verschillen in het informeel leren tussen flexwerkers en mensen met een vast contract aanzienlijk kleiner. De mate van flexibiliteit van het contract blijkt zelfs geen significante rol te spelen wanneer er gecontroleerd wordt voor geslacht, leeftijd en opleidingsniveau. Dit suggereert dat informeel leren als bron van nieuwe kennis en vaardigheden even belangrijk is voor alle werkenden, ongeacht het arbeidscontract dat zij hebben.

- Zzp'ers doen vaker aan zelfstudie en besteden daar ook meer uren aan dan werkenden in loondienst. Dit suggereert dat zelfstandigen hun achterstand in cursusdeelname deels compenseren door meer tijd te investeren in het op eigen houtje verwerven van nieuwe kennis en vaardigheden.

- Het motief om aan cursussen deel te nemen verschilt sterk naar de aard van het arbeidscontract. Werkenden met een vast contract volgen in vergelijking met flexwerkers en zelfstandigen relatief vaak een cursus, omdat er op hun werk een nieuwe manier van werken is geïntroduceerd. Belangrijke motieven voor de deelname aan cursussen bij de werkenden met een flexibel contract zijn onder meer het vergroten van de kans op werk en de kans op een vaste baan. Driekwart van de zelfstandigen volgt een cursus om aan hun klanten meer kwaliteit te kunnen leveren. Daarnaast blijken circa vier op de tien zelfstandigen cursussen te volgen met het oog op het verhogen van hun omzet, of om te leren hoe zij nieuwe klanten kunnen aantrekken. Ook volgen zij vaker een cursus om hun loopbaandoelen te realiseren.

- Een beleidsmatige interessante vraag is in welke mate flexbanen aantrekkelijker worden gevonden als ze veel mogelijkheden bieden om nieuwe kennis en vaar- 
digheden te verwerven. Onze analyses laten zien dat het belang dat werkenden hechten aan de mogelijkheid om in een tijdelijke functie op het werk veel te kunnen leren onvoldoende is om tijdelijke banen een echt aantrekkelijk alternatief te maken voor vaste banen die weinig leermogelijkheden bieden. Een hogere beloning in een tijdelijke baan lijkt echter werknemers wel te compenseren voor het gebrek aan zekerheid in de baan. In dat geval kiezen ze vaker voor een tijdelijk contract.

\section{Deelname aan scholing door oudere werknemers is verder toegenomen}

- De scholingsdeelname onder ouderen is tussen 2007 en 2010 toegenomen. Deze toename heeft zich doorgezet tussen 2010 en 20I3. Uit eerder onderzoek komt naar voren dat de afschaffing van de prepensioenregelingen een mogelijke verklaring is voor de toegenomen cursusdeelname onder oudere werkenden: het perspectief om langer door te moeten werken vergroot de terugverdienperiode van investeringen in menselijk kapitaal en dus de prikkel om scholing te volgen. Met de verhoging van de AOW-leeftijd kan worden verwacht dat de cursusdeelname van oudere werkenden de komende jaren verder zal stijgen.

- De scholing van 55-plussers vindt vaker plaats op initiatief van de werkgever en is vaker gericht op hun huidige baan. Dit verklaart waarom werkgevers net zo vaak voor de cursusdeelname van 55-plussers als voor jongere werknemers. Een goed HR-beleid blijkt de scholingsdeelname onder oudere werknemers te stimuleren. Bovendien hebben oudere werknemers in vergelijking met jongere werknemers minder ambitieuze doelen voor ogen bij het volgen van cursussen. De scholingsinspanningen van ouderen zijn vooral gericht op de interne arbeidsmarkt bij hun huidige werkgever in plaats van op de externe arbeidsmarkt. Hierdoor zijn oudere werknemers erg kwetsbaar bij baanverlies.

- De kennisontwikkeling neemt af met het stijgen van de leeftijd; het bijbenen van technologische en organisatorische veranderingen blijkt moeilijker wanneer de leeftijd toeneemt en oudere werkenden schatten hun employability lager in dan jongere werkenden. Vanuit beleidsoogpunt zijn er echter interessante verschuivingen gaande. Zo ontwikkelt de kennisontwikkeling van 55-plussers zich de afgelopen jaren gunstig: in 2010 en 2013 lag de kennisontwikkeling van 55-plussers op een hoger niveau dan in de jaren daarvoor, en is de afnemende employability met het oplopen van de leeftijd in de jaren 2010 en 2013 minder sterk dan in de jaren daarvoor. Het volgen van scholing versterkt daarbij de employability van oudere werkenden. 

en niet-werkenden. ${ }^{3}$ In 2013 gaf ruim de helft (53\%) van de werkenden aan in de afgelopen twee jaar te hebben deelgenomen aan een cursus. Na een kleine dip in 2007 herstelde de cursusdeelname van de werkenden zich weer. Onder de niet-werkenden lag de trainingsdeelname in 2013 circa $30 \%$-punt lager (22\%) dan onder de werkenden. ${ }^{4}$ Wel is er bij de niet-werkenden sinds 2007 sprake van een lichte (maar statistisch niet significante) toename van de cursusdeelname. De stabiliteit in cursusdeelname over de jaren is opmerkelijk in het licht van de economische crisis.

In 2013 rondde ongeveer driekwart van de respondenten de gevolgde cursussen af met een diploma. Dit geldt zowel voor werkenden als voor niet-werkenden. Ongeveer een kwart geeft aan dat dit niet het geval was, omdat er bij de cursus

Driekwart van de cursussen leidt tot diploma of certificaat

geen diploma of certificaat behaald kon worden. Slechts I\% heeft geen diploma of certificaat behaald, terwijl dit in de praktijk wel mogelijk was geweest. Onder hoogopgeleiden zijn er verhoudingsgewijs veel werkenden die een cursus volgden waarbij er na afloop geen diploma of certificaat verstrekt werd. Dit wijst er op dat hoogopgeleiden een ander soort cursussen volgen dan middelbaar of laagopgeleiden. ${ }^{5}$

3. De definitie van werkenden in dit hoofdstuk gaat uit van de belangrijkste bezigheid van de respondent: I) betaald werk in loondienst, 2) werkzaam of meewerkend in een gezins- of familiebedrijf 3) vrije beroepsbeoefenaar, freelancer of zelfstandige.

4. Het verschil tussen werkenden en niet-werkenden is stabiel over de jaren, ook nadat gecontroleerd is voor mogelijke veranderingen in samenstelling naar leeftijd, opleiding en geslacht over de jaren.

5. Laagopgeleiden zijn personen met maximaal vmbo. Middelbaar opgeleiden zijn personen met een havo/vwo of mbo diploma. Hoogopgeleiden zijn afgestudeerden met een diploma op hbo niveau of hoger. 


\section{Figuur 1.1}

Formeel leren: ontwikkeling van de deelname aan cursussen en trainingen, 2004-2013')

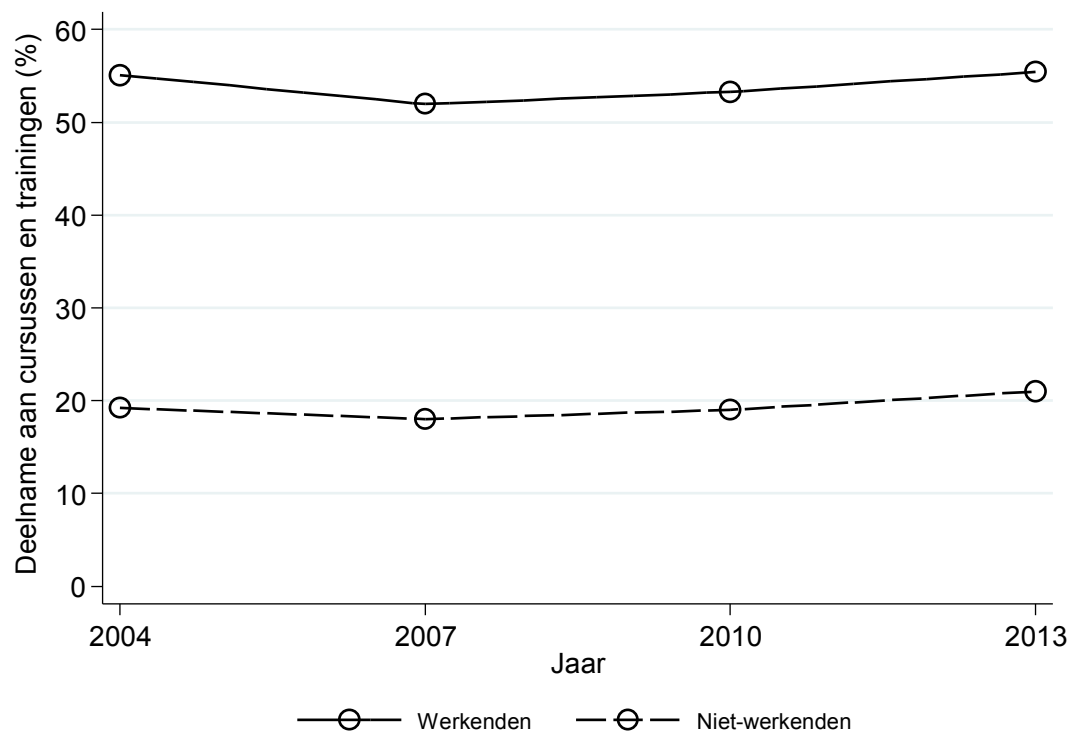

1) De verschillen tussen werkenden en niet-werkenden zijn significant. De verschillen tussen de vier metingen zijn binnen beide groepen echter niet significant.

Figuur I.2 laat de trainingsdeelname van de werkenden zien, gedifferentieerd naar geslacht. Tussen 2004 en 2013 deed zich een opmerkelijke ontwikkeling voor. Terwijl de trainingsdeelname van werkende vrouwen in 2004 en 2007 nog achterbleef bij die van hun mannelijke collega's, vond er na 2007 een duidelijke kentering plaats. In 2010 maakten vrouwen hun achterstand op dit vlak al in belangrijke mate goed, maar in 2013 blijken werkende vrouwen voor het eerst iets vaker cursussen en trainingen te volgen dan werkende mannen. Hoewel het verschil met I\%-punt marginaal is, is deze kentering een interessante ontwikkeling die vooral is toe te schrijven aan de stijgende scholingsdeelname onder hoogopgeleide vrouwen. ${ }^{6}$

6. Deze convergentie wordt niet alleen gedreven door verandering in de samenstelling van de groep werkende vrouwen. Wij vinden ook een convergentie in scholingsdeelname naar geslacht in analyses waarin op leeftijd en opleiding wordt gecontroleerd. 


\section{Figuur 1.2}

Formeel leren: ontwikkeling cursusdeelname werkende mannen en vrouwen, 2004-2013')

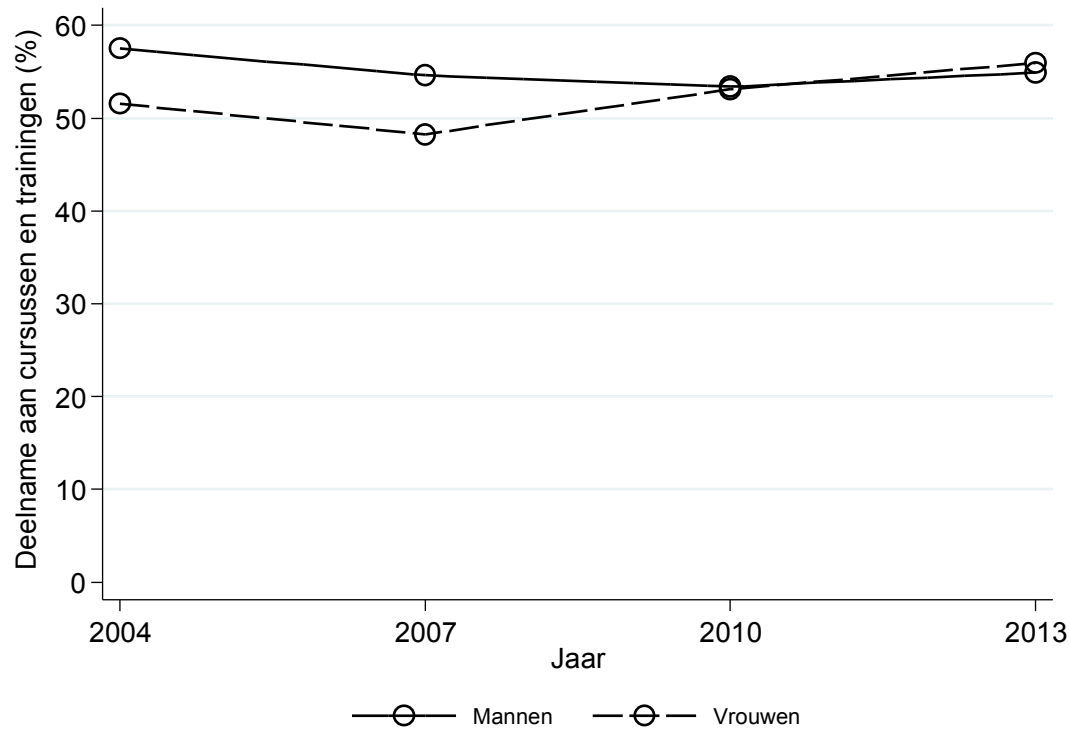

1) De verschillen tussen werkende mannen en vrouwen zijn significant in 2004 en 2007, maar niet in 2010 en 2013.

Verder blijkt dat de kloof in de scholingsdeelname tussen enerzijds de laagopgeleiden en anderzijds de middelbaar- en hoogopgeleiden tussen 2004 en 2013 is gegroeid. Dit komt doordat de deelname aan cursussen en training door laagopgeleiden gedaald is van $46 \%$ in 2004 naar $37 \%$ in 2013 , terwijl de deelname aan cursussen en trainingen door hoogopgeleiden in beide jaren $64 \%$ was. Van de middelbaar opgeleiden nam zowel in 2004 als in $201353 \%$

Kloof in scholingsdeelname tussen laag-opgeleiden versus middelbaaren hoogopgeleiden is tussen 2004 en 2013 toegenomen deel aan scholing. Uit eerder onderzoek blijkt dat het aanbod van cursussen door werkgevers geen aannemelijke verklaring is voor de kloof in scholingsdeelname tussen laag- en hoogopgeleiden (Maximiano 20II). Er is ook geen verschil in het rendement van cursussen tussen laag- en hoogopgeleiden (in termen van het verkrijgen van een hogere loon), maar de bereidheid van laagopgeleiden om cursussen te volgen is lager (Fouarge et al. 2013). Het verschil in scholingsbereidheid tussen de opleidingsniveaus kan worden verklaard aan de hand van persoonlijkheidskenmerken, zoals bijvoorbeeld examenangst (Fouarge et al. 2013).

Nadere analyses voor werkenden laten zien dat de kans dat iemand nog nooit eerder in zijn of haar carrière een training gevolgd heeft afneemt wanneer zijn of haar oplei- 
dingsniveau toeneemt. Het zijn vooral lager opgeleiden alsook personen met havo/ vwo als hoogst genoten opleiding die nog nooit een training hebben gevolgd sinds ze aan het werk zijn. Mbo'ers hebben op hun beurt vaker nog nooit een training gevolgd dan hoger opgeleiden. De mate waarin men nog nooit aanvullende scholing heeft gevolgd verschilt ook naar bedrijfssector. Zo had in 2013 de helft van de werkenden in de horeca van 35 jaar en ouder nog nooit een training gevolgd. Ook in de handel (31\%), cultuur $(35 \%)$ en ideële $\&$ belangenorganisaties $(38 \%)$ hadden ruim drie op de tien medewerkers naar eigen zeggen nog nooit een training gevolgd. Bij werkenden in de energie- of waterwinning komt dit aanmerkelijk minder vaak voor (9\%). Geslacht en leeftijd hebben een veel kleinere invloed op het feit of werkenden nog nooit een cursus gevolgd hebben.

In sommige gevallen blijken werkenden zelf graag een cursus voor hun werk te willen volgen, maar moeten ze daar door omstandigheden van af zien. Zo geeft I4\% van de werkenden aan dat zij in de afgelopen twee jaar zelf een cursus wilden volgen, maar dat zij hierin niet gesteund werden door hun werkgever. Daardoor ging de cursus uiteindelijk niet door. Voor $7 \%$ van de werkenden ging de cursus wegens omstandigheden niet door terwijl zij wel de steun hadden van hun werkgever.

\section{Cursusdeelname naar leeftijd}

In het vorige rapport was er een verschuiving zichtbaar in de scholingsdeelname naar leeftijd (Borghans et al. 20II): jongeren waren tussen 2004 en 2010 minder aan scholing gaan deelnemen en 55-plussers juist meer. In 2013 is de deelname aan cursussen en trainingen onder jongeren terug op het niveau van 2004, terwijl de scholingsdeelname onder 55-plussers verder is gestegen (figuur 1.3 ). ${ }^{7}$ Een mogelijke verklaring voor de stijging in scholings-

\section{Scholingsdeelname van ouderen is in} 2013 verder gestegen

deelname door jongeren is de aanhou-

dende crisis die de arbeidsmarktperspectieven voor jongeren beperkt (ROA 20I3) en jongeren dwingt tot verdere scholing om de kansen op de arbeidsmarkt te vergroten. Zo blijkt dat jongeren in economisch onzekere tijden vaker het vergroten van de mogelijkheden om een baan te vinden als motief noemen voor het volgen van een cursus. ${ }^{8}$ Een mogelijke oorzaak voor deze verdere stijging is dat de afschaffing van prepensioenregelingen en de verhoging van de AOW-leeftijd er toe leiden dat oudere werknemers meer in hun menselijk kapitaal investeren omdat zij langer actief

7. Onder 55-66 jarigen is de deelname aan cursussen en trainingen gestegen van $24 \%$ in 2004 naar $35 \%$ in 2013. Voor werkenden in de leeftijd 55-66 jaar is de deelname aan cursussen en trainingen gestegen van $40 \%$ in 2004 naar $52 \%$ in 2013 .

8. Het kan echter ook zijn dat de werkgever in een ruime arbeidsmarkt vaker scholing gebruikt als selectie instrument (voor de jongste leeftijdsgroep in de data vindt scholing vaker op initiatief van de werkgever plaats en wordt het ook vaker door de werkgever betaald), of dat werkgevers vinden dat de kennis en vaardigheden van jonge instromers op de arbeidsmarkt niet goed aansluit bij hun vraag waardoor bijscholing noodzakelijk is. 
verwachten te blijven op de arbeidsmarkt (zie Fouarge en de Grip 20I4). Ook de toenemende aandacht van bedrijven voor de positie van oudere medewerkers zou hieraan kunnen hebben bij gedragen (zie Montizaan et al. 20I0).

\section{Figuur 1.3}

Formeel leren: ontwikkeling van deelname aan cursussen en trainingen door werkenden naar leeftijd, 2004-2013")

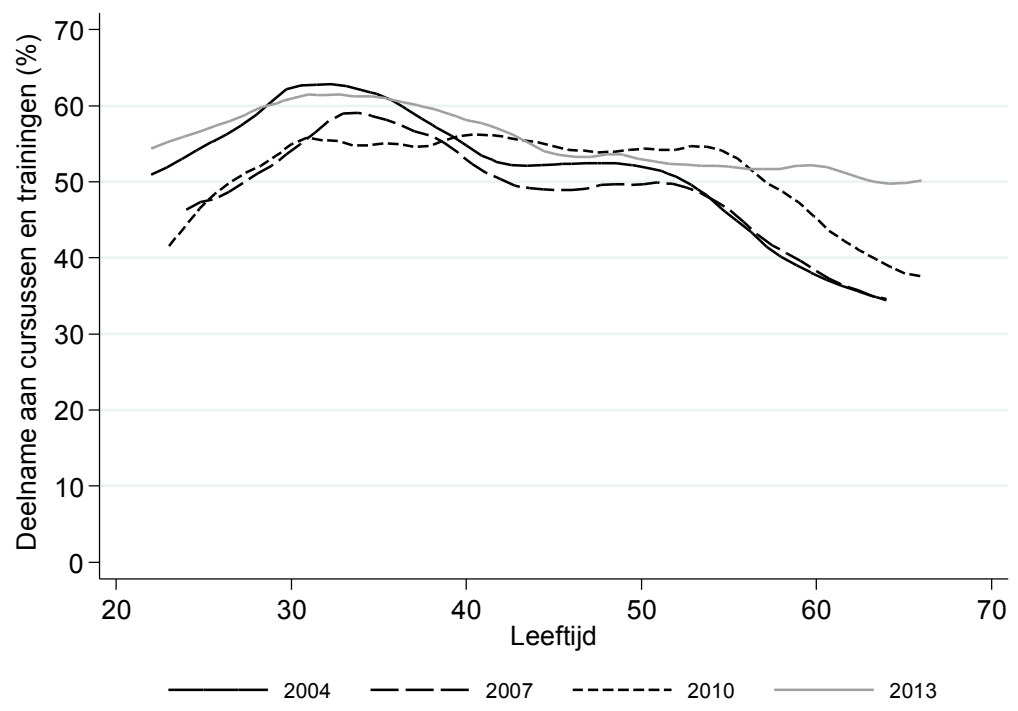

1) De toename van de scholingsdeelname bij de 55-plussers tussen 2007 en 2010 is significant. De toename tussen 2010 en 2013 is niet statistisch significant.

\section{Intensiteit van cursussen}

De werkenden die scholing volgenden zijn sinds 2004 iets meer cursussen en trainingen gaan volgen. Tijdens de eerste meting in 2004 gaven werkenden die cursussen hebben gevolgd aan dat zij gemiddeld aan 2,4 cursussen en trainingen in de twee voorgaande jaren hadden deelgenomen. Dit komt overeen met jaarlijks gemiddeld I,2

Intensiteit cursussen afgenomen tussen 2004 en 2013, maar meer zo voor laag-dan hoogopgeleiden cursussen. In 2013 is dit toegenomen tot 2,7 cursussen en trainingen in de twee voorgaande jaren (I,35 per jaar). Daarbij blijkt uit figuur I.4 dat de mediane duur van cursussen (in termen van het aantal dagen) is afgenomen van 5 naar 3 dagen, maar dat het aantal uren dan men besteedt aan cursussen per dag juist is toegenomen van 5 
naar 7.9 Per saldo kan men dus concluderen dat de intensiteit van een gemiddelde cursus tussen 2004 en 2013 is afgenomen van 25 uur per cursus naar 2I uur per cursus. Zowel voor hoog-, middelbaar-, als laagopgeleiden kan geconcludeerd worden dat de tijd die aan cursussen besteed wordt in 2013 flink is afgenomen ten opzichte van 2004, waarbij de afname het grootst is bij laagopgeleiden: van 20 uur naar 15 uur gemiddeld per cursus voor laagopgeleiden en van 30 uur naar 27 uur voor hoogopgeleiden. Dit betekent dat de ongelijkheid in de scholingsintensiteit tussen hoog- en laagopgeleiden is toegenomen, niet alleen in termen van het percentage werkenden dat aan scholing doet, maar ook in termen van de scholingsduur.

\section{Figuur 1.4}

Cursusdeelname van werkenden: mediaan aantal dagen en aantal uren per dag 2004- 2013'

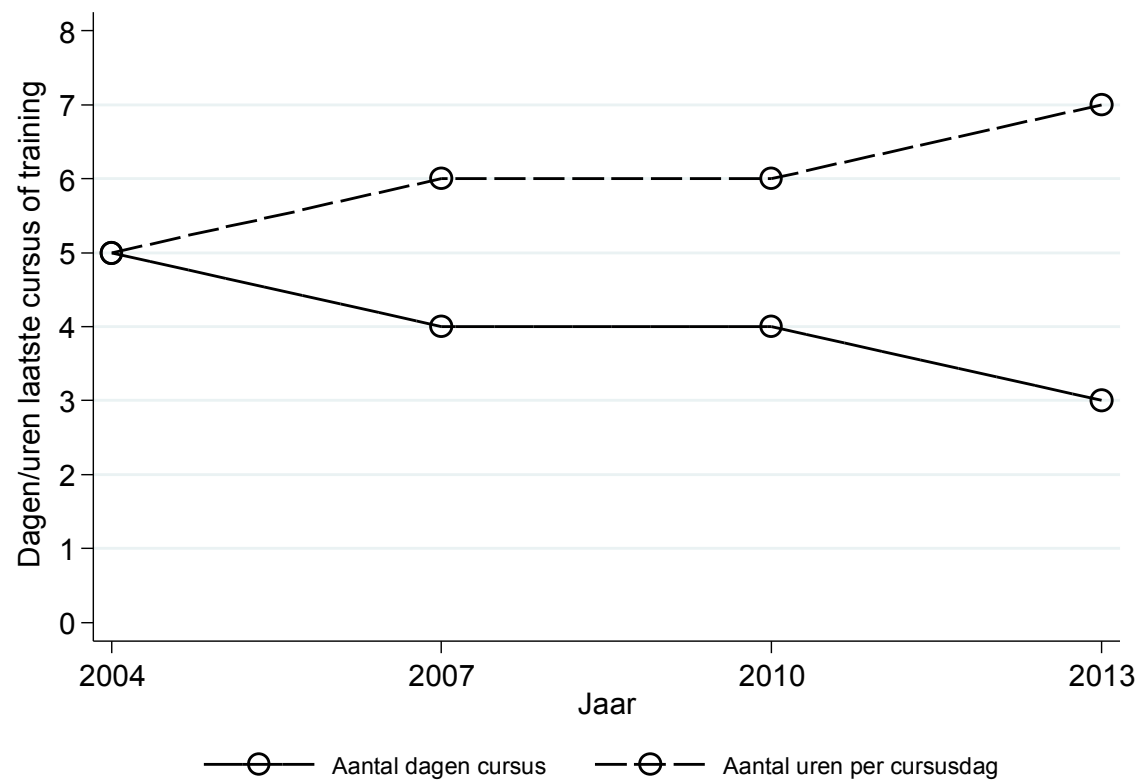

1) De trends in aantal dagen en aantal uren zijn significant.

Wat men leert kan men soms niet gelijk op het werk in de praktijk brengen. In 2013 bleken respondenten ongeveer 8 uur nodig te hebben om wat zij geleerd hebben tijdens de cursus op hun werk toe te kunnen passen. Bij laagopgeleiden (4 uur) is dit echter minder dan bij hoogopgeleiden (Io uur).

9. Bij een kwart van de werkenden die in 2013 aan een cursus hebben deelgenomen heeft de cursus I dag geduurd. Bij I8\% heeft deze cursus 2 dagen geduurd. Bij 7 op de Io heeft de cursus maximaal 5 dagen geduurd. Het aantal uren besteed aan cursussen heeft betrekking op het aantal uren besteed aan de cursus zelf en het aantal uren besteed aan huiswerk. 


\section{Motieven voor scholing}

Welke beweegredenen hebben werkenden om aan cursussen en trainingen deel te nemen? Tabel I.I laat voor werknemers in loondienst zien in welke mate verschillende motieven van invloed waren op hun afweging om aan een cursus deel te nemen. ${ }^{\circ}$ De vaakst genoemde reden (39\%) is 'ik ben op cursus gegaan omdat deze verplicht was'. Dit duidt er op dat werkenden lang niet altijd zelf het initiatief nemen ten aanzien van hun eigen ontwikkeling. Laagopgeleiden noemen deze reden zelfs in de helft van alle gevallen. Uit de tabel blijkt overigens dat deze reden aanzienlijk minder vaak genoemd wordt wanneer het opleidingsniveau toeneemt. Een andere reden die vaak ten grondslag ligt aan het volgen van een cursus is het realiseren van eigen loopbaandoelen (36\%). Dit motief wordt twee keer zo vaak aangevoerd door hoogopgeleiden $(40 \%)$ dan door laagopgeleiden $(2 \mathrm{I} \%)$. Ook geven hoger opgeleiden vaker aan dat ze een cursus volgen om promotie te maken. Daarentegen zijn de verschillen tussen de opleidingsniveaus betrekkelijk klein bij de andere motieven om scholing te volgen, zoals onvoldoende kennis, het krijgen van nieuwe taken, een grotere baankans en een hoger inkomen.

Tabel 1.1

Redenen voor het volgen van cursus, werkenden naar opleidingsniveau, 2013 ${ }^{1)}$

\begin{tabular}{lcccc} 
& Totaal (\%) & Laag (\%) & Middelbaar (\%) & Hoog (\%) \\
\hline Cursus verplicht & 39 & 50 & 42 & 32 \\
Realiseren loopbaandoelen & 36 & 21 & 35 & 40 \\
\hline Kennis/ervaring onvoldoende & 33 & 32 & 30 & 37 \\
\hline Nieuwe taken gekregen & 30 & 36 & 29 & 30 \\
\hline Nieuwe manier van werken & 23 & 23 & 23 & 22 \\
Baankans vergroten & 22 & 23 & 23 & 21 \\
\hline Als waardering voor goed functioneren & 16 & 19 & 16 & 14 \\
\hline Promotie kunnen maken & 15 & 10 & 15 & 17 \\
\hline Hoger inkomen & 12 & 12 & 13 & 11 \\
Waardering krijgen van leidinggevende & 7 & 9 & 5 & 8 \\
1) Respondenten mochten meerdere antwoorden aanvinken. & &
\end{tabular}

Ook is gekeken naar de relatie tussen de deelname aan cursussen en trainingen en de tevredenheid van werkenden over verschillende aspecten van hun werk. Degenen die een cursus hebben gevolgd blijken significant vaker tevreden te zijn met de werksfeer, de inhoud van hun werk, loopbaanperspectieven en scholingsmogelijkheden. De interpretatie van deze relaties is echter niet eenduidig. Het kan betekenen dat het deelnemen aan scholing in positieve zin bijdraagt aan de tevredenheid van werkenden. Het kan echter ook betekenen dat werknemers die meer tevreden zijn

Io. Respondenten konden voor elk motief aangeven in welke mate zij het daar mee eens waren op een schaal van I 'helemaal niet mee eens' tot 7 'helemaal mee eens'. De gepresenteerde cijfers in tabel I.I hebben betrekking op het percentage dat 5 of meer als antwoord gaf. 
over deze aspecten van het werk eerder geneigd zijn om aan scholingsactiviteiten deel te nemen, of deze vaker aangeboden krijgen door hun werkgever. Opmerkelijk is ook dat degenen die een cursus hebben gevolgd niet tevredener zijn met hun salaris en met de zelfstandigheid die ze hebben in hun functie.

\section{Initiatief tot scholing en kosten van scholing}

Op de vraag bij wie het initiatief lag voor het volgen van de cursus wordt niet eenduidig geantwoord. Van de werkenden die in de afgelopen twee jaar een cursus gevolgd hebben geeft in $201337 \%$ aan dat het initiatief bij de werkgever lag, 34\% zegt zelf de initiator te zijn geweest voor de cursusdeelname en de overige $29 \%$ geeft Hoogopgeleiden nemen vaker zelf het initiatief tot cursusdeelname. Bij laagopgeleiden en 55-plussers is dit vaker de werkgever aan dat dit in samenspraak tussen werkgever en werknemer is gebeurd. Hoogopgeleiden gaven veel vaker (43\%) aan dat zij zelf de initiator voor de cursusdeelname waren dan middelbaar- en laagopgeleiden (ongeveer een kwart). Onder laagopgeleiden lag het initiatief voor de cursusdeelname juist bijna twee keer zo vaak bij de werkgever (54\%) dan bij hoogopgeleiden (28\%). Ook bij 55-plussers werd de cursusdeelname relatief vaak geïnitieerd door de werkgever.

Op de vraag wie de cursus of training betaald heeft komt een duidelijk antwoord. In $87 \%$ van de gevallen wordt deze door de werkgever betaald. Gemiddeld heeft minder dan IO\% van de werkenden deze zelf betaald. In slechts $3 \%$ van de gevallen betaalden werkgever en werknemer een deel van de kosten. Werknemers die zelf de kosten van de cursus of training hebben betaald rapporteren minder vaak dat deze gericht was op de huidige baan. Dit is in lijn met voorspelling uit de menselijk kapitaal

Werkgevers betalen even vaak voor scholing van 55-plussers als voor scholing van jongere werknemers theorie.

Hoogopgeleiden betalen de cursus vaker zelf (in $13 \%$ van de gevallen, vergeleken met $5 \%$ onder de laagopgeleiden). Ook vrouwen betalen vaker zelf voor de cursus, terwijl bij mannen de cursus significant vaker door de werkgever wordt betaald. Echter, deze aan geslacht gerelateerde verschillen vallen weg als er gecontroleerd wordt voor de sector van activiteit. Werkgevers betalen net zo vaak de cursusdeelname van 55-plussers als van jongere werknemers.

Naast deze directe kosten van scholing zijn er ook indirecte kosten voor de werkgever en de werknemers die afhankelijk zijn van het feit of de cursus onder werktijd of tijdens de vrije tijd van de werknemer is gevolgd. Van de tijd die gepaard gaat met het 
volgen van de cursus zelf is tweederde gevolgd in de baas z'n tijd. De tijd besteed aan huiswerk heeft daarentegen vooral (55\%) betrekking op vrije tijd.

\section{Transfer van kennis}

In 2013 gaf ongeveer driekwart van de werkenden die in de voorbije twee jaar een cursus gevolgd hebben aan dat zij na afloop van de cursus het geleerde goed tijdens hun werk hebben kunnen toepassen. Dit wordt in de wetenschappelijke literatuur ook wel aangeduid als transfer van kennis en vaardigheden naar de werkvloer (De Grip en Sauermann 2013).

Doordat cursusdeelnemers het geleerde na afloop in sommige gevallen overbrengen op hun collega's ontstaan er bovendien zogenoemde spillover effecten. Collega's leren indirect van de cursus zonder hier zelf bij aanwezig te zijn geweest. Evenals in 2010 geeft in 2013 iets minder dan de helft van degenen die een cursus hebben Bij circa 50\% van de gevolgde cursussen profiteren collega's ook van de opgedane kennis en vaardigheden gevolgd aan dat zij de opgedane kennis en vaardigheden hebben overgedragen aan hun collega's.

\section{Bedrijfsspecifieke training}

De in de cursus ontwikkelde kennis en vaardigheden blijken in de regel vooral bedrijfs- of branchespecifiek te zijn. Van alle werkende cursusdeelnemers vindt $83 \%$ de cursus goed bruikbaar in het huidige werk. Bovendien vindt $79 \%$ de

Opgedane kennis en vaardigheden blijken vooral bedrijfs- of branchespecifiek cursus goed bruikbaar wanneer zij bij een andere organisatie in dezelfde branche zouden gaan werken. Van alle cursusdeelnemers verwacht $44 \%$ het in de cursus geleerde ook te kunnen gebruiken wanneer zij in een andere branche zouden gaan werken. Hier gaat het dus waarschijnlijk om cursussen die gericht zijn op de ontwikkeling van meer generieke competenties. Er is daarbij geen relatie tussen het volgen van cursussen die meer gericht zijn op vaardigheden die bruikbaar zijn in andere organisaties in andere branches en wie het initiatief heeft genomen voor de cursus of wie hiervoor betaald heeft. 


\subsection{Ontwikkelingen in informele leren en zelfstudie}

Naast het volgen van cursussen en trainingen kan het informeel leren tijdens het werk belangrijk zijn voor het verder ontwikkelen van iemands kennis en vaardigheden. Arrow (1962) wees al op het belang van learning-by-doing in de jaren zestig. Aan de respondenten is daarom gevraagd hoeveel procent van hun werktijd zij besteden aan taken waarvan zij kunnen leren. ${ }^{\text {II }}$ Nadat het percentage van de werktijd dat besteed wordt aan informeel leren licht afnam tussen 2004 en 2010 van $31 \%$ naar

Sterke toename van informeel leren tijdens het werk tot $35 \%$ van de werktijd $28 \%$, vond er in 2013 een sterke en significante stijging plaats (figuur I.5). In 2013 gaven werkenden aan dat zij $35 \%$ van hun werktijd aan informeel leren besteed hadden. ${ }^{12}$ Dit wijst erop dat in steeds meer bedrijven sprake is van een leerrijke werkomgeving (De Grip en Van Loo 2002). Een andere mogelijke verklaring is dat werknemers de afname in de cursus intensiteit compenseren door meer informeel leren.

\section{Figuur 1.5}

Informeel leren: ontwikkeling van het percentage van de werktijd besteed aan activiteiten waarvan men kan leren, 2004-2013')

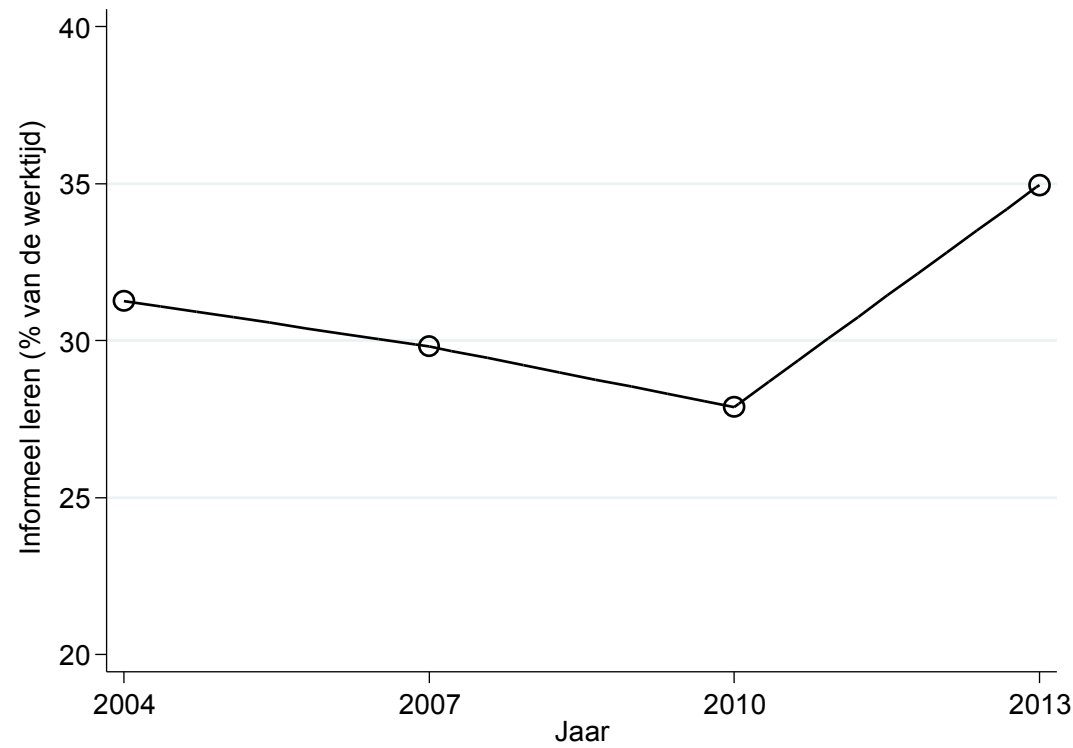

1) De trend in informeel leren tussen 2004 en 2010 is significant, zo ook de toename in informeel leren tussen 2010 en 2013.

II. Zie Borghans et al. (2006) voor een verantwoording van de meting van informeel leren.

I2. Ook de mediaan laat een significante stijging zien tussen 2010 en 2013. 
Werkende vrouwen besteden gemiddeld genomen een iets groter deel van hun werktijd aan werkzaamheden waarvan ze leren dan werkende mannen. Tussen 2004 en 2010 nam zowel voor mannen als vrouwen de werktijd waarin men leerde af. In 2013 is dit percentage echter weer flink gestegen met respectievelijk 6\%-punt bij der mannen en $9 \%$-punt bij de vrouwen. Het verschil in informeel leren tussen vrouwen $(37 \%)$ en mannen $(33 \%)$ in 2013 is significant. Een differen-

Vrouwen besteden op hun werk meer tijd aan leerzame taken dan mannen. En hoogopgeleiden meer dan laagopgeleiden. tiatie van de resultaten naar opleidingsniveau laat zien dat hoogopgeleiden meer werktijd hebben waarin ze informeel leren (38\%) dan middelbaar- (35\%) en laagopgeleiden (26\%). De sterke algemene stijging van het informeel leren tussen 2010 en 2013 blijkt in belangrijke mate toe te schrijven aan de toename in informeel leren onder hoogopgeleiden (+6\%-punt) en in het bijzonder middelbaar opgeleiden (+10\%-punt). Onder lager opgeleiden blijft dit percentage sinds 2007 stabiel.

\section{Figuur 1.6}

Informeel leren: ontwikkeling van het percentage van de werktijd besteed aan activiteiten waarvan men kan leren naar leeftijd, 2004-2013'1)

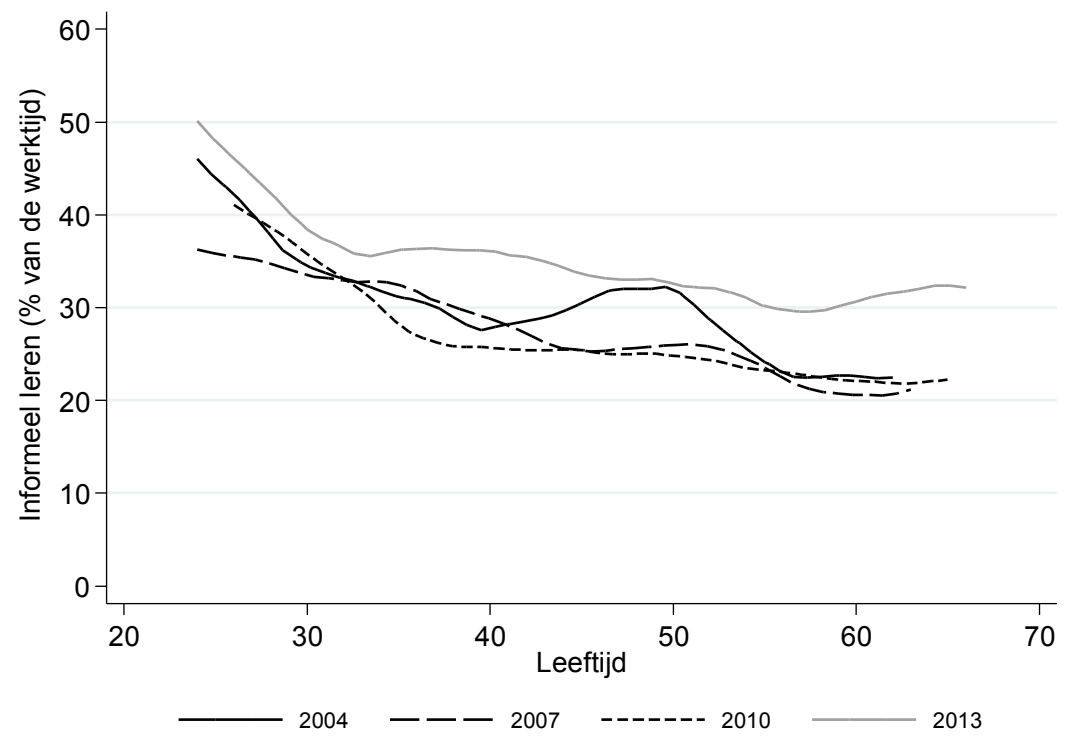

\footnotetext{
1) De afname van het informeel met het stijgen van de leeftijd is significant in alle enquêtejaren.
} 
Figuur I.6 laat zien hoe het informeel leren voor de verschillende leeftijdsgroepen zich de afgelopen jaren heeft ontwikkeld. De mate waarin iemand tijdens het werk leert blijkt duidelijk af te nemen met het oplopen van de leeftijd. Dit patroon is de afgelopen jaren niet significant veranderd. Het informeel leren tijdens het werk blijkt in 2013 echter voor alle leeftijdsgroepen op een hoger niveau te liggen dan in eerdere jaren.

Werkenden die tevens één of meer vormen van formele training hebben gevolgd, besteden in de regel ook significant meer tijd aan werkzaamheden waarvan ze informeel leren dan werkenden die geen formele training hebben gevolgd (+5\%-punt). Degenen die een training hebben gevolgd besteden in 2013 gemiddeld $37 \%$ van hun werktijd aan werkzaamheden waarvan ze leren, terwijl degenen die geen training volgden gemiddeld $32 \%$ van hun werktijd aan informeel leren

\section{Werkenden die training volgen leren ook meer op het werk} besteden. In alle vier de metingen van de ROA Levenslang Leren Enquête is er sprake van een significante positieve relatie tussen de cursusdeelname en het informeel leren tijdens het werk. ${ }^{13}$ Echter, zowel voor degenen die wel training volgden als degenen die geen training volgden is er tussen 2010 en 2013 sprake van een sterke stijging in het informeel leren tijdens het werk.

\section{Totale tijd besteed aan leeractiviteiten}

Als we het percentage van de werktijd dat werkenden in 2013 aan informeel leren besteden $(35 \%)$ relateren aan het gemiddeld aantal gewerkte uren, dan krijgen we een beeld van de gemiddelde tijd waarin men op het werk leert. Uit deze berekening komt naar voren dat een gemiddelde werkende in 2013 zo'n 484 uur besteedde aan het informeel leren tijdens het werk. ${ }^{\mathrm{I}}$ Dit is bijna Ioo uur meer dan in 2010 toen dit

Informeel leren vormt $96 \%$ van de totale tijd besteed aan leren nog 386 uur was. Deze 484 uur die gemiddeld aan informeel leren werd besteed is ook aanzienlijk meer dan de $2 \mathrm{I}$ uur die in 2013 gemiddeld aan formeel leren werd besteed. Door de tijd die aan formeel en informeel leren werd besteed, respectievelijk 2 I uur en 484 uur, bij elkaar op te tellen wordt de totale tijd verkregen waarin werkenden in 2013 leerden. Een gemiddelde werkende besteedde in 2013 derhalve 505 uur aan activiteiten waar hij of zij van kon leren. Van deze totale tijd bestond veruit het grootste deel (96\%) uit het informeel leren op het werk. Daarentegen heeft slechts $4 \%$ van het leren van werkenden betrekking op het volgen van cursussen en trainingen. Ter vergelijking, in 2004 was de verhouding formeel-informeel leren $8 \%-92 \%$

I3. Deze correlatie blijft significant nadat gecontroleerd wordt voor geslacht, leeftijd en opleiding.

I4. Dit is berekend als $35 \%$ van I. 384 uren. Dit is het gemiddeld aantal gewerkte uren in Nederland. Hierbij is uitgegaan van de meest recente cijfers van het CBS (voorlopig cijfer 20I2). 
en in $20107 \%-93 \%$. Dit wijst er op dat in de afgelopen jaren een steeds groter deel van de totale leertijd betrekking heeft op het informeel leren tijdens het werk.

\section{Werkzaamheden waarvan men leert}

Het werk van werkenden bestaat uit het uitvoeren van verschillende soorten activiteiten, zoals het uitvoeren van alledaagse routine werkzaamheden, vergaderen, maar ook het uitvoeren van taken die nieuw zijn of een uitdaging vormen. Figuur I.7 laat zien voor een negental taken de mate waarin men daarvan leert op een schaal van I 'erg weinig' tot 5 'erg veel'. Werkenden leren het meest van nieuwe en uitdagende werkzaamheden, en het minst van alledaagse routine werkzaamheden. Er wordt ook relatief minder geleerd van vergaderen en overleggen, het schrijven van documenten, berekeningen maken en het samenwerken met minder ervaren collega's.

\section{Figuur 1.7}

Mate waarin men leert van verschillende werkzaamheden op het werk, 2013

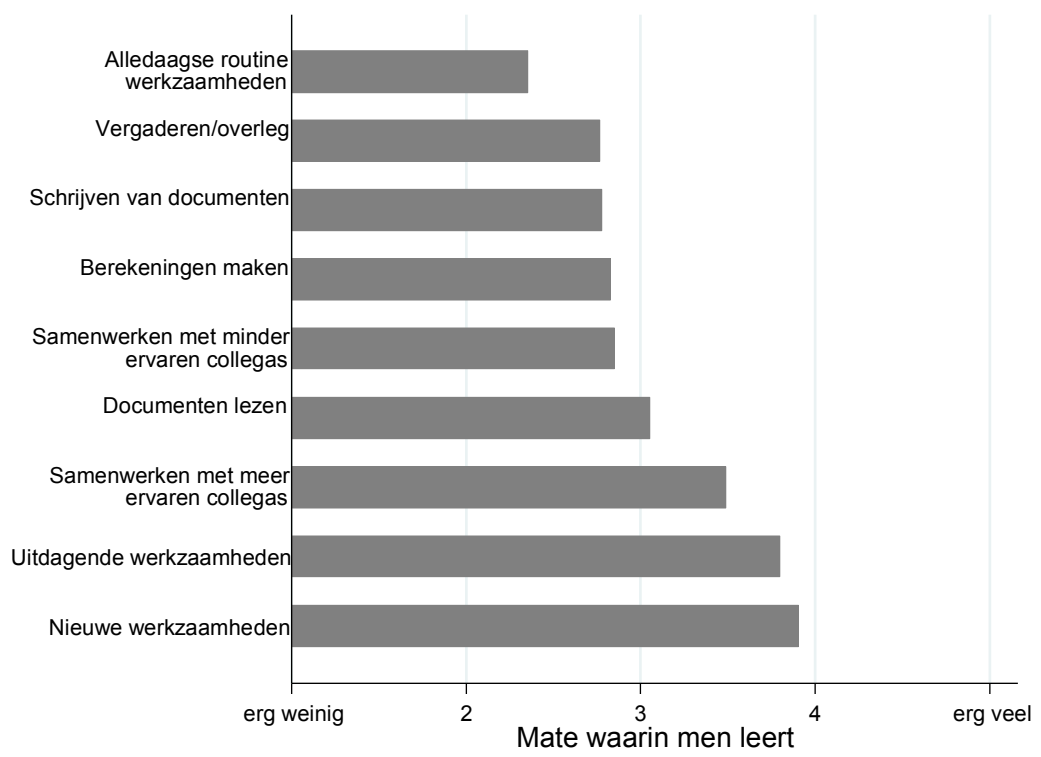

Vrouwen leren meer dan mannen van vergaderen en de samenwerking met meer of minder ervaren collega's. Hoogopgeleiden leren minder van routine werkzaamheden dan laagopgeleiden, maar weer meer van werkzaamheden waarvoor zij voor een uitdaging staan, werkzaamheden die ze niet eerder hebben gedaan, samenwerken met meer ervaren collega's, documenten lezen of berekeningen maken. Tussen de verschillende leeftijdsgroepen blijken er weinig verschillen te zijn. Vooral de jongste werkenden (I6-24 jaar) leren veel van de samenwerking met meer ervaren collega's, terwijl 45-plussers relatief minder leren van werkzaamheden die ze niet eerder hebben gedaan. 
Werknemers in Nederland besteden veel tijd aan taken waarvan zij kunnen leren. Dit roept de vraag op hoe groot het leerrendement van het informeel leren is alsook de vraag hoe dit rendement zich verhoudt tot het leerrendement van formele trainingen en cursussen. In de ROA Levens-

\section{Leerrendement van trainingen en} informeel leren is vrijwel gelijk lang Leren Enquête is aan werkenden gevraagd of zij meer of minder leren van een cursus van 8 uur dan van 8 uur informeel leren op het werk. ${ }^{\text {Is }}$ Hoewel men misschien zou kunnen denken dat iemand meer leert van een uur cursus of training dat alleen het leren als doel heeft dan van een uur waarin men werk doet waarvan men leert, blijken werkenden per uur formeel en informeel leren gemiddeld genomen ongeveer evenveel te leren. Dit betekent dat er geen verschil is in het leerrendement van formeel en informeel leren. Omdat werknemers echter veel meer uren besteden aan het leren tijdens hun werk dan aan het volgen van cursussen of trainingen, kunnen wij concluderen dat informele leeractiviteiten voor werkenden veruit de belangrijkste bron van nieuwe kennis en vaardigheden vormen. Daarbij zijn er geen significante leeftijdsverschillen in het leerrendement van formeel en informeel leren. Het is opmerkelijk dat vrouwen een significant hoger rendement van informeel leren rapporteren dan mannen. Datzelfde geldt voor hoogopgeleiden ten opzichte van laagopgeleiden.

\section{Zelfstudie}

Naast het volgen vancursussen en trainingen en het informeel leren tijdens het werk kan men ook nieuwe kennis en vaardigheden leren via zelfstudie. ${ }^{16}$ In de 2013 peiling van de ROA Levenslang Leren Enquête is aan respondenten gevraagd hoeveel uren zij in de afgelopen maand hebben besteed aan zelfstudie thuis, dat wil zeggen zelfstandig leren of kennis bijhouden door middel van vakliteratuur zonder dat dit gerelateerd was aan een cursus. ${ }^{17}$

I5. De vraag is alleen gesteld aan werkenden die in de afgelopen twee jaar of langer geleden een cursus hebben gevolgd. De vergelijking betrof 4 of 8 uren cursus en leren op het werk waarbij de waarden 4 en 8 zijn gerandomiseerd. Er zijn geen significante verschillen in de antwoorden naar de wijze van vraagstelling.

16. Met zelfstudie wordt hier bedoeld de tijd die thuis besteed wordt aan zelfstandig leren of kennis bijhouden door middel van handboeken of (vak)literatuur zonder dat dit gerelateerd is aan een cursus.

I7. In de vraagstelling is gerandomiseerd naar de periode waarin zelfstudie gerapporteerd moest worden: in de afgelopen $\mathrm{I} 2$ maanden, 6 maanden, of I maand. Hieruit blijkt dat de vraagstelling niet van invloed is op de gerapporteerde uren besteed aan zelfstudie. 
Van alle werkenden deed in 2013 4I\% thuis aan zelfstudie. Gemiddeld genomen besteedt men per maand ongeveer 3 uur aan zelfstudie. Zoals verwacht zou kunnen worden doen hoogopgeleiden meer aan zelfstudie (4 uur per maand) $41 \%$ van werkenden doet thuis aan zelfstudie; gemiddeld 3 uur per maand dan middelbaar opgeleiden ( 3 uur per maand) en laagopgeleiden (I uur per maand). Werkende mannen (4 uur per maand) doen twee keer zoveel aan zelfstudie dan werkenden vrouwen ( 2 uur per maand). Naar leeftijd zijn er ook grote verschillen. Jongere werkenden van I6-24 jaar doen nauwelijks aan zelfstudie, terwijl 35-44 jarigen per maand 5 uur besteden aan zelfstudie. De overige leeftijdsgroepen besteden per maand 2 uur aan zelfstudie. Ook de niet-werkenden besteden gemiddeld genomen 2 uur per maand aan zelfstudie.

\subsection{Trends in de kennisontwikkeling}

Leeractiviteiten, of het nu gaat om formeel leren, informeel leren of zelfstudie, leiden tot de ontwikkeling van kennis en vaardigheden, waardoor mensen hun werkzaamheden beter kunnen uitvoeren. Deze kennisontwikkeling wordt gemeten door respondenten eerst te vragen naar de kennis en vaardigheden die in hun ogen nodig zijn om hun werk op een optimale manier uit te kunnen voeren. Vervolgens wordt hen gevraagd om hun eigen kennispeil in te schatten op verschillende momenten in hun carrière. Hierbij wordt het niveau dat nodig is om in hun werk optimaal te functioneren op roo gezet. ${ }^{18} \mathrm{Om}$ iemands kennisontwikkeling in de afgelopen twee jaar te kunnen bepalen, kijken we naar het verschil tussen het huidige kennisniveau en het kennisniveau van twee jaar geleden.

Het zelf ingeschatte huidige kennisniveau van werkenden (83\%) ligt in 2013 19\%-punt boven dat van niet-werkenden (65\%). Onder werkenden is het kennisniveau, op een significante daling in 2010 na, elke meting vrijwel constant. Onder niet-werkenden was het kennisniveau tussen 2004 en 2010 vrijwel constant, maar vond er in 2013 een significante toename plaats. Dit laatste illustreert dat er met het oplopen van de werkloosheid sprake is van een toenemende onderbenutting van de competenties van degenen die aan de zijlijn staan.

Gemiddeld genomen gaven werkenden in 2013 aan dat er in de twee voorafgaande jaren sprake was van een kennistoename van 7,I\%-punt (figuur I.8). Dit is significant lager dan in 2004, toen nog een kennistoename van 9,I\%-punt werd gemeten, in 2007 was dit nog 8,5\%-punt

In 2013 hadden werkenden 7,1\%-punt meer kennis en vaardigheden dan twee jaar daarvoor en in 2010 8,I\%-punt. Merk echter op

I8. Aan niet-werkenden is gevraagd om de functie die zij het liefst zouden bekleden als uitgangspunt te nemen. 
dat het huidige kennisniveau om optimaal te kunnen functioneren en het kennisniveau van twee jaar geleden in 2013 door werkenden hoger ingeschat worden dan in voorgaande jaren. Dit zou echter het gevolg kunnen zijn van de vergrijzing van de werkzame bevolking als ook van een afnemende doorgroei naar een hoger functieniveau in de economische crisis waardoor werkenden meer ervaring opbouwen in hun huidige functie.

\section{Figuur 1.8}

Kennisontwikkeling: ontwikkeling van de toename van kennis en vaardigheden van werkenden in de afgelopen twee jaar, 2004-2013")

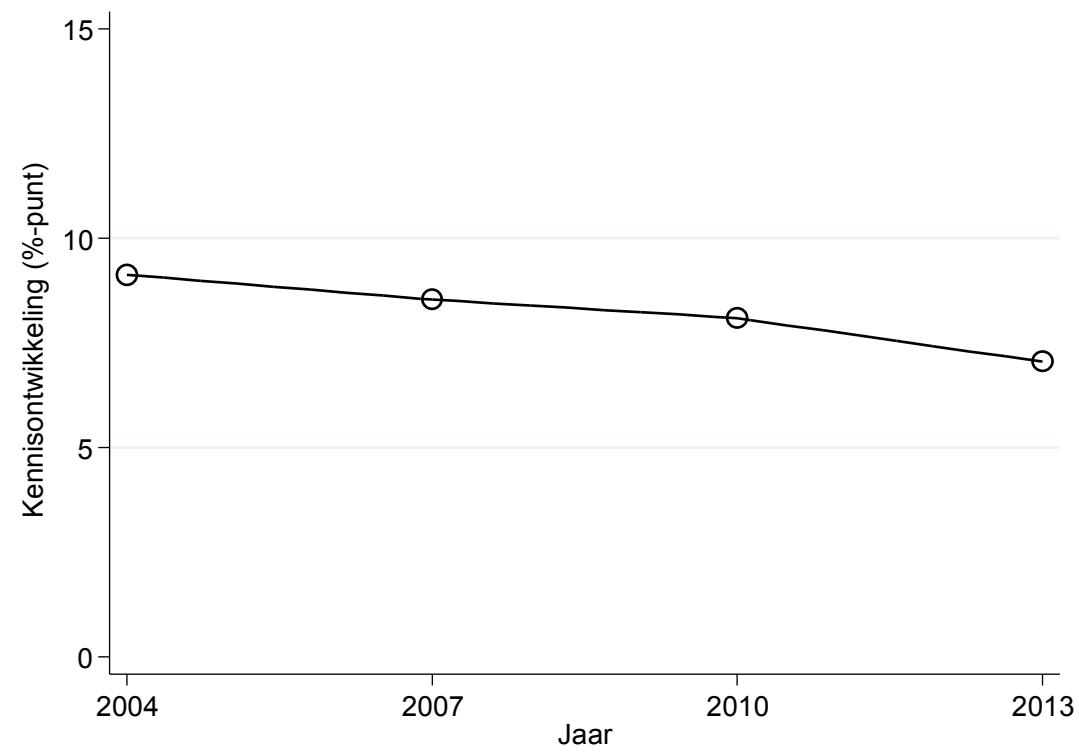

1) De negatieve trend in kennisontwikkeling is significant.

Figuur I.9 brengt de kennisontwikkeling van werkenden voor de verschillende leeftijdsgroepen in beeld. De figuur laat duidelijk zien dat in alle enquêtejaren de kennisontwikkeling afneemt met het stijgen van de leeftijd. De figuur suggereert echter ook dat de kennisontwikke-

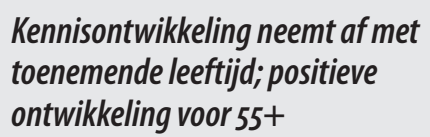

ling van 55-plussers zich de afgelopen jaren gunstig heeft ontwikkeld: in 2010 en 2013 lag de kennisontwikkeling van 55-plussers op een hoger niveau dan in de jaren daarvoor. De kennisontwikkeling onder werkenden is positief gerelateerd aan cursusdeelname en het informeel leren tijdens het werk. Het is daarentegen niet gerelateerd aan de mate waarin men aan zelfstudie doet. ${ }^{19}$ De met de leeftijd afnemende kennis-

I9. Ook onder niet-werkenden is het aantal uren besteed aan zelfstudie niet gerelateerd aan de kennisontwikkeling. 
ontwikkeling kan verklaard worden uit hun lagere scholingsdeelname en het feit dat oudere werknemers minder leren tijdens het werk, maar het zou ook kunnen samenhangen met hun geringere mobiliteit op de arbeidsmarkt (zie Borghans et al. 20II).

\section{Figuur 1.9}

Kennisontwikkeling van werkenden in de afgelopen twee jaar naar leeftijd, 2004-20131)

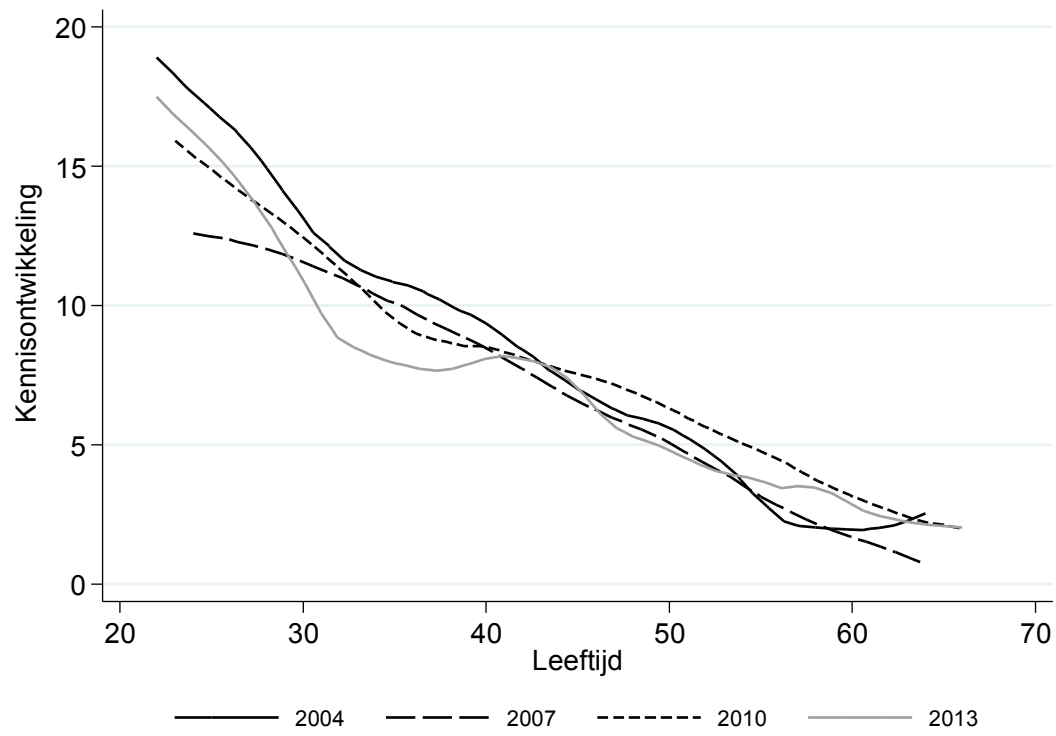

1) De afname van de kennisontwikkeling met het stijgen van de leeftijd is significant in alle enquêtejaren. Ook de toename van de kennisontwikkeling bij ouderen in 2010-2013 is significant.

\subsection{Leren, employability en mobiliteit}

Verandering van werkgever en verandering van werkzaamheden kunnen leiden tot veranderingen in de deelname aan scholing, informeel leren en de opbouw van menselijk kapitaal ('kennisontwikkeling'). Daarom wordt in deze paragraaf onderzocht welke ontwikkelingen zich de afgelopen jaren hebben voorgedaan in de employability, het risico op baanverlies en de verwachte baanmobiliteit van werknemers.

De ROA Levenslang Leren Enquête maakt de employability van respondenten inzichtelijk door hen de volgende vraag voor te leggen: "Hoe groot schat u de kans dat, als $\mathrm{u}$ nu op zoek zou moeten gaan naar een andere baan, u een baan zou kunnen krijgen van vergelijkbaar niveau als uw huidige baan?”. Respondenten kunnen hierbij kiezen uit een vijf-puntsschaal die oploopt van I) zeer onwaarschijnlijk tot 5) zeer waarschijnlijk. Op vergelijkbare wijze wordt gevraagd in hoeverre ze de kans reëel achten dat ze in de komende vijf jaar hun baan verliezen. De verwachte baanmobiliteit binnen 
nu en vijf jaar wordt gemeten aan de hand van twee vragen. Allereerst is aan respondenten gevraagd of zij over vijf jaar bij een ander bedrijf zouden willen werken. De tweede vraag gaat een stap verder en toetst of respondenten verwachten dat zij over vijf jaar daadwerkelijk bij een ander bedrijf werken. In beide gevallen is opnieuw gebruik gemaakt van een vijf-puntsschaal. Bij de vraag of men over vijf jaar bij een ander bedrijf wil werken loopt deze schaal van I) zeker niet tot 5) erg graag, bij de vraag over de kans dat dit daadwerkelijk het geval zal zijn van I) zeer onwaarschijnlijk tot 5) zeer waarschijnlijk.

Figuur I.IO geeft voor de vier enquêtejaren 2004, 2007, 2010 en 2013 de indicatoren weer voor de employability van werkenden, het risico op baanverlies in de komende vijf jaar en de baanmobiliteit (over vijf jaar andere baan willen hebben en de verwachte kans op een andere baan). In de vier metingen schatten werkenden hun employability (in termen van de kans dat zij, als zij op dat moment hun baan kwijtraken, op een vergelijkbaar niveau een andere baan zullen vinden) gemiddeld genomen op '50-50' (antwoordmo-

In de crisisjaren 2010 en 2013 schatten werkenden hun employability significant lager in dan in 2007 gelijkheid 3). Werkenden blijken hun employability in de crisisjaren 2010 en 2013 echter significant lager in te schatten dan in 2007 . Ook de afname tussen 2010 en 2013 is significant. In 2013 is het verwachte risico op baanverlies ook significant hoger dan in 2007 en 20IO. Dit laat duidelijk zien dat de perceptie van werkenden rond baanzekerheid de feitelijke ontwikkelingen op de arbeidsmarkt volgt: stijgende werkloosheid in tijden van crisis resulteert in een negatiever beeld van de eigen employability en baanzekerheid bij degenen die (nog) wel werk hebben.

De twee indicatoren voor baanmobiliteit zijn beschikbaar vanaf 2007. Er zijn in alle jaren meer werkenden die over vijf jaar bij een ander bedrijf zouden willen werken dan dat er verwachten tegen die tijd daadwerkelijk bij een ander bedrijf te werken. Beide indicatoren kennen een vergelijkbaar verloop. In 2013 is er ten opzichte van 2007 en 2010 een significant groter aantal werkenden dat verwacht over vijf jaar in een andere baan te zullen werken: vermoedelijk gaat het hierbij om verwacht onvrijwillige mobiliteit als gevolg van de aanhoudende economische crisis. Onderzoek laat immers zien dat werknemers meer honkvast zijn in perioden van laagconjunctuur (Loog et al. 20I4). 


\section{Figuur 1.10}

Verwachtingen van werkenden op het gebied van hun employability ${ }^{1}$, risico op baanverlies in komende vijf jaar en baanmobiliteit over 5 jaar, 2004-2013

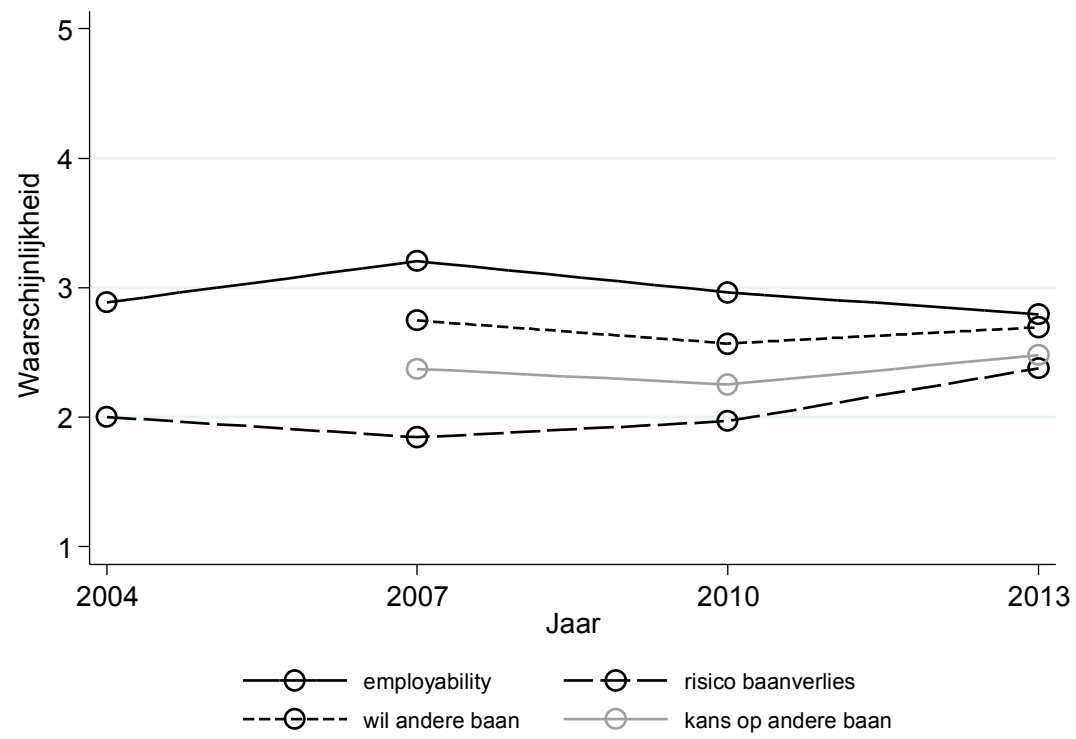

1) Kans dat men een baan zou vinden als men op zoek moet naar een baan.

Figuur I.II geeft een beeld van de employability van werkenden naar leeftijd over de jaren 2004-2013. Uit de figuur blijkt dat oudere werkenden hun employability lager inschatten dan jongere werkenden. Echter, de met de leeftijd afnemende employability is in 2010 en 2013 minder

Ouderen schatten hun employability lager in dan jongeren sterk dan in eerdere jaren. Dit wijst er op dat de employability van oudere werknemers langzamerhand iets verbetert. 


\section{Figuur 1.11}

Ontwikkeling van de employability van werkenden naar leeftijd, 2004-20131)

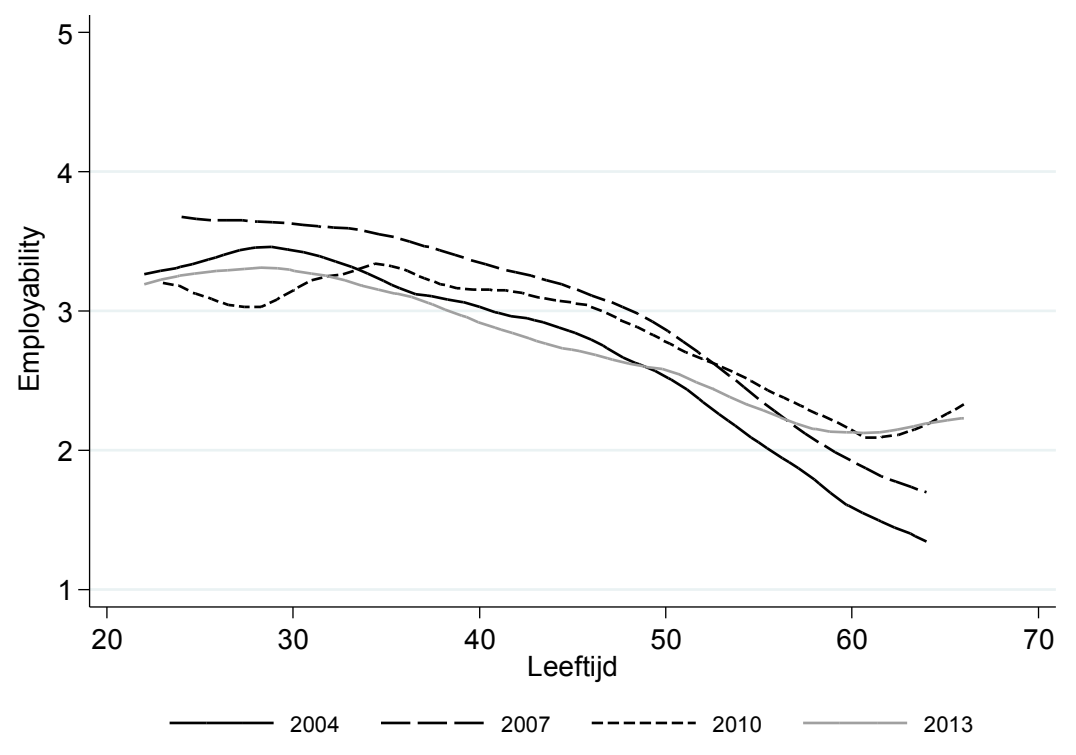

1) Het patroon van de met de leeftijd afnemende employability is significant.

Figuur I.I2 laat voor de periode 2004-20I3 de ontwikkeling zien van de kans dat werkenden van verschillende leeftijdsgroepen in de komende vijf jaar hun baan verwachten te verliezen. De figuur laat duidelijk zien dat werkenden ongeacht hun leeftijd in 2013 vaker vrezen In 2013 zijn werkenden in alle leeftijdsgroepen banger om hun baan kwijt te raken dan in de jaren daarvoor hun baan te verliezen dan in de jaren daarvoor. 


\section{Figuur 1.12}

Ontwikkeling van de kans op baanverlies in de komende 5 jaar naar leeftijd, 2004-2013

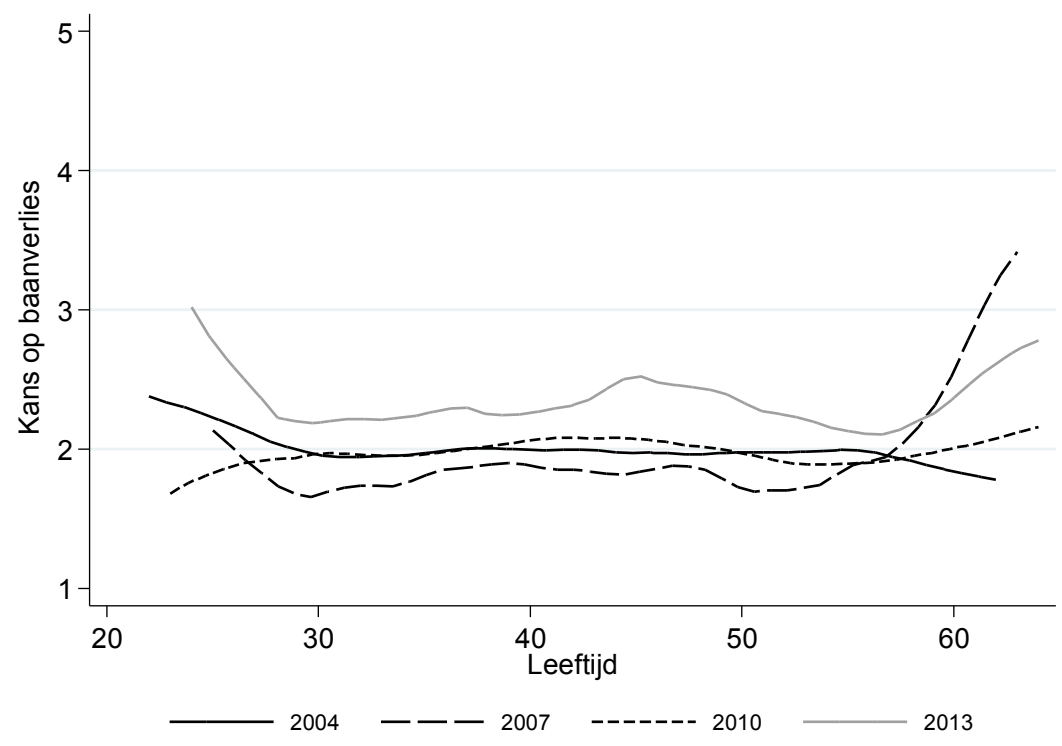

\section{Formeel en informeel leren en employability}

Werkenden die een cursus hebben gevolgd en/of meer informeel leren tijdens hun werk verwachten minder risico te lopen om hun baan te verliezen. De relatie met de gepercipieerde employability is weliswaar positief, maar niet significant. Degenen die meer leren tijdens hun werk hebben ook vaker de wens over vijf jaar bij een ander bedrijf te werken en verwachten dat dit ook het geval zal zijn. Dit is niet het geval bij degenen die een cursus of training hebben gevolgd. Degenen die meer aan zelfstudie doen hebben geen positiever beeld van hun risico op baanverlies, maar wel van hun employability, dat wil zeggen de kans dat ze bij verlies van hun werk weer een baan kunnen krijgen op een vergelijkbaar niveau. 


\section{Formeel en informeel leren door flexwerkers}

In dit hoofdstuk gaan we nader in op de verschillen in leren op het werk tussen werknemers met een vast dienstverband, flexwerkers en zelfstandigen. Uit eerder onderzoek blijkt dat flexwerkers halverwege de jaren 2000 minder vaak deelnemen aan door de werkgever bekostigde scholing dan vaste krachten, maar vaker participeren in door henzelf bekostigde scholing (Fouarge et al. 20I2). Hoe dit verschil zich sindsdien heeft ontwikkeld is onbekend. Ook is er weinig bekend over het motief achter de scholingsbeslissing van flexkrachten. Wordt scholing gevolgd om de eigen kansen op de arbeidsmarkt te verbeteren, of omdat scholing noodzakelijk is om bij te blijven bij de veranderingen in de werktaken?

De enquêteresultaten die in dit hoofdstuk worden gepresenteerd hebben uitsluitend betrekking op 2013 en zijn afkomstig van het CentERpanel aangevuld met LISS. ${ }^{20}$ Het grootste voordeel van het toevoegen van respondenten uit de LISS is dat in deze steekproef bewust geselecteerd is op werkenden in flexibele banen en zelfstandigen (zie bijlage A), waardoor het aantal waarnemingen van werkenden zonder een vast contract zich goed leent voor meer gedetailleerde analyses.

In dit hoofdstuk wordt achtereenvolgens ingegaan op de relatie tussen flexibele arbeid en de deelname aan verschillende vormen van leren (paragraaf 2.I), de bekostiging van scholing (paragraaf 2.2) en de motieven voor het volgen van scholing (paragraaf 2.3). Paragraaf 2.4 sluit dit hoofdstuk af met de vraag of, en in welke mate, aspecten van het werk zoals de mogelijkheden tot informeel leren en het loon kunnen compenseren voor de onzekerheid die gepaard gaat met de tijdelijke aard van een dienstverband.

\subsection{Cursusdeelname, informeel leren en zelfstudie}

Allereerst is het belangrijk om af te bakenen wie in dit hoofdstuk tot de "flexibele schil" kunnen worden gerekend. Het CBS hanteert de volgende definitie voor flexwerkers: "Werknemers met een flexibel dienstverband (flexwerkers) zijn werknemers zonder vast dienstverband. Zij hebben een arbeidscontract van beperkte duur en/of

20. In hoofdstuk I is omwille van de vergelijkbaarheid met de eerdere enquêtejaren uitsluitend gebruik gemaakt van data van het CentERpanel. 
een arbeidscontract zonder een vast overeengekomen aantal uren in dienst". Hierbij onderscheidt het CBS de volgende verschijningsvormen van flexwerkers: uitzendkrachten, oproep- of invalkrachten, en personen met een tijdelijk dienstverband. In de literatuur worden echter nog meer verschillende vormen van flexibele arbeid benoemd (Zijl 2006). In dit hoofdstuk onderscheiden we daarom zes contractvormen. In afnemende mate van flexibiliteit zijn dit achtereenvolgens werkenden met een:

- vast contract;

- vast contract met flexibele kenmerk(en), zoals bijvoorbeeld detachering vanuit de eigen werkgever of een aanstelling bij een payroll organisatie;

- tijdelijk contract met uitzicht op vast contract;

- tijdelijk contract zonder uitzicht op vast contract en zonder flexibele kenmerk(en);

- tijdelijk contract op bijvoorbeeld uitzend-, afroep- of oproepbasis;

- zelfstandig ondernemer (doorgaans gaat het hierbij om zelfstandigen zonder personeel).

Volgens het CBS had in $201368 \%$ van de werkenden een vast dienstverband ${ }^{21}$, $17 \%$ een flexibel dienstverband en was $15 \%$ werkzaam als zelfstandige. De data van de $R O A$ Levenslang Leren Enquête 2013 maken een verdergaande opsplitsing van de flexwerkers mogelijk. Bovendien worden degenen die een vast dienstverband hebben met een duidelijk flexibel kenmerk (bv. in dienst bij een payroll bedrijf) ook tot de flexwerkers gerekend.

Figuur 2.I geeft een overzicht van de werkenden in 2013 naar het type contract dat zij hebben. Ongeveer $63 \%$ van de werkenden heeft een vast contract zonder enig flexibele kenmerk. Nog eens $7 \%$ heeft een contract dat getypeerd kan worden als vast, maar met de kanttekening dat het contract tevens één of meerdere kenmerk(en) vertoont van een flexibel contract. Deze personen hebben weliswaar een vast dienstverband bij hun werkgever, maar worden bijvoorbeeld aan derden uitgeleend of gedetacheerd. Verder heeft $7 \%$ een tijdelijk contract, waarbij er in de nabije toekomst uitzicht is op een vast contract. In de praktijk betekent dit vaak dat een tijdelijk contract door de werkgever als screeninginstrument gebruikt wordt. In dat geval krijgt de werknemer, na gebleken geschiktheid, alsnog een contract voor onbepaalde tijd. Nog eens $6 \%$ heeft een tijdelijk contract zonder dat er uitzicht is op een vast contract. Verder heeft $8 \%$ van de werkenden een tijdelijk contract op uitzend-, afroep- of oproepbasis. Ten slotte is $9 \%$ van de werkenden zelfstandige, freelancer, vrije beroepsbeoefenaar of meewerkende in een familiebedrijf. ${ }^{22}$ Deze laatste groep heeft overwegend betrekking op zelfstandigen zonder personeel (zzp'ers).

2I. Personen die een arbeidsovereenkomst hebben die niet van beperkte duur is én die voor een vast overeengekomen aantal uren in dienst zijn.

22. Het percentage vaste krachten $(63 \%+7 \%)$ in onze data komt redelijk overeen met de cijfers van het CBS. Vergeleken met de CBS cijfers is echter sprake van een ondervertegenwoordiging van zelfstandigen in de enquêtes. 
Figuur 2.1

Verdeling werkenden naar contractvorm, 2013 (percentages)

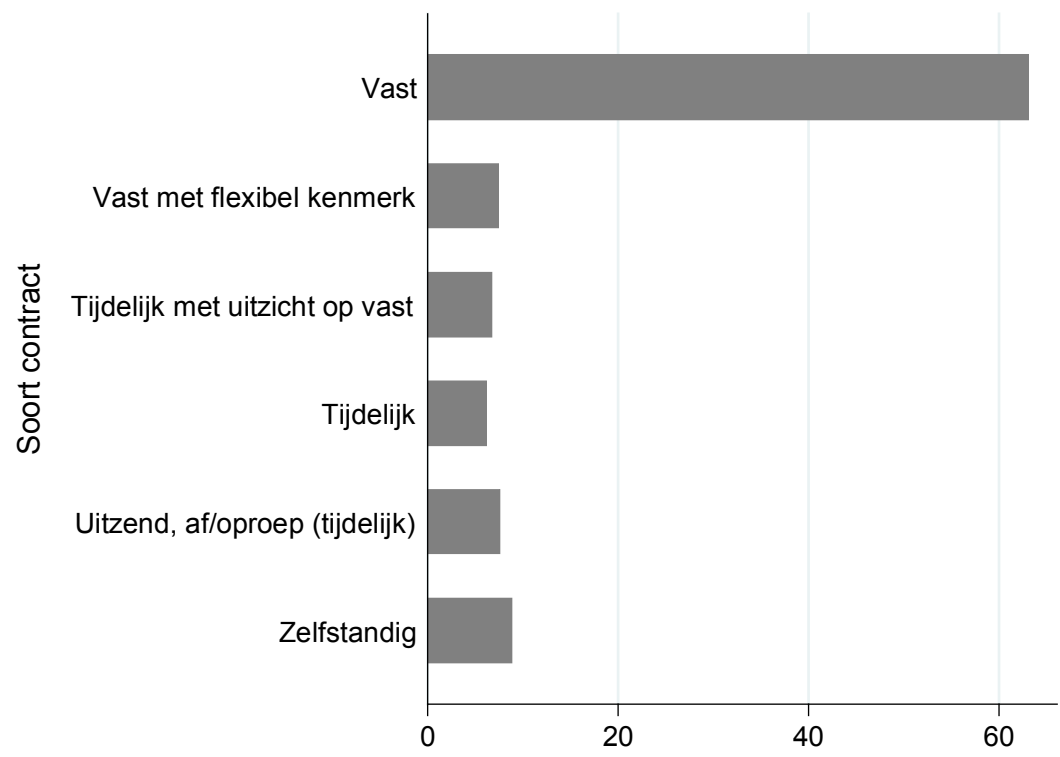

Vaak zijn werkgevers eerder geneigd om te investeren in menselijk kapitaal als medewerkers in permanente dienst zijn dan wanneer ze tijdelijk bij hen in dienst zijn, of ingeleend worden. Dit wordt doorgaans verklaard vanuit het feit dat werkgevers zelf de vruchten willen plukken van deze investeringen en die kans is eenvoudigweg het grootst bij medewerkers met een vast contract. Over de relatie tussen het soort contract dat werkenden hebben en het informeel leren tijdens het werk en zelfstudie is veel minder bekend. Op basis van de data van de ROA Levenslang Leren Enquête kunnen we echter zowel de cursusdeelname als het informeel leren en de zelfstudie voor elk van de zes hiervoor besproken contractvormen in beeld brengen. Figuur 2.2 laat per contractvorm zien welk deel van de werkenden in de afgelopen twee jaar een cursus of training heeft gevolgd, welk deel van hun werktijd zij aan activiteiten besteed hebben waarvan zij kunnen leren (het informeel leren) en in welke mate men aan zelfstudie doet.

\section{Formeel leren}

De verschillen in de mate van trainingsdeelname tussen de contractvormen waren in 2013 aanzienlijk. Werkenden met een vast contract blijken het vaakst deel te nemen aan training of cursussen. Bijna zes op de tien werknemers met een vast contract hebben in de afgelopen twee jaar tenminste één cursus of training gevolgd. Ook werkenden met een vast contract met flexibele kenmerken en werkenden met een tijdelijk contract met uitzicht op een vast contract volgen vaker training (voor beide 
groepen is dit $48 \%$ ) dan werkenden met een meer flexibele contractvorm. Werknemers met een tijdelijk contract zonder uitzicht op een vast contract volgen het minst vaak training. Van deze groep heeft $28 \%$ in de afgelopen twee jaar een cursus of training gevolgd. Uitzendkrachten en zelfstandigen blijken ongeveer even vaak scholing te volgen: ongeveer $37 \%$ van hen heeft in de afgelopen twee jaar een cursus of training gevolgd.

Ook wanneer gecontroleerd wordt voor leeftijd, geslacht en opleidingsniveau blijkt dat werkenden met een vast contract significant vaker getraind worden dan flexibele krachten. ${ }^{23}$ Bovendien blijkt dat flexwerkers met een tijdelijk contract zonder uitzicht op een vast

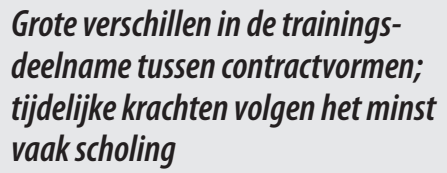
contract en uitzend-, afroep- en oproepkrachten significant vaker dan werkenden met een vast contract gedurende hun arbeidsloopbaan nog nooit enige vorm van training hebben gevolgd.

Werkenden met een vast contract met flexibele kenmerken volgden de afgelopen twee jaar de meeste cursussen. Ze besteedden bovendien naast de cursus significant meer tijd om het geleerde op hun werk onder de knie te krijgen. Gemiddeld volgden zij in twee jaar tijd 3 cursussen per persoon. Flexibele werkers met een tijdelijk contract zonder uitzicht op een vast contract en uitzend-, afroep- en oproepkrachten volgden in die periode gemiddeld respectievelijk 2,2 en 2,4 cursussen. Ook na controle voor leeftijd, geslacht en opleidingsniveau blijkt dat werkenden met een vast contract met flexibele kenmerken significant meer, en uitzend-, afroep- en oproepkrachten significant minder cursussen volgen dan werknemers in vaste dienst.

Een vergelijking tussen de verschillende typen contracten leert verder dat er nauwelijks verschillen bestaan in het al dan niet behalen van een diploma of certificaat na afloop van de cursus. Werkenden met een tijdelijk contract met uitzicht op een vast contract vormen hierop de enige uitzondering in positieve zin. Werkenden met een dergelijk contract hebben de cursus significant vaker met een diploma of certificaat afgesloten dan werkenden met een andere contractvorm. Wellicht dat voor deze groep het uitzicht op een vaste aanstelling samenhangt met het behalen van een officiële kwalificatie.

23. Nadat gecontroleerd wordt voor de bedrijfssector waarin iemand werkzaam is, blijkt nog steeds dat tijdelijke krachten zonder uitzicht op een vast dienstverband, uitzend- en oproepkrachten en zelfstandigen significant minder vaak aan scholing deelnemen dan vaste krachten. Nadat gecontroleerd wordt voor de bedrijfssector zijn de verschillen in cursusdeelname tussen de medewerkers met een vaste aanstelling en de vaste krachten met een flexibel kenmerk en tijdelijke krachten met uitzicht op een vaste aanstelling niet significant. 
De tijdens de cursus opgedane kennis en vaardigheden van uitzend-, afroep- en oproepkrachten en personen met een tijdelijk contract zonder uitzicht op een vast contract blijken in de praktijk significant minder goed toepasbaar in hun huidige werk dan het geval is voor werknemers met een vast dienstverband. Dit suggereert dat deze typen flexibele krachten, als ze zich scholen, aan cursussen deelnemen met een breder of ander toepassingsgebied dan dat van hun huidige functie.

\section{Figuur 2.2}

Mate van formeel leren, informeel leren en zelfstudie naar contractvorm, 2013 ${ }^{1)}$

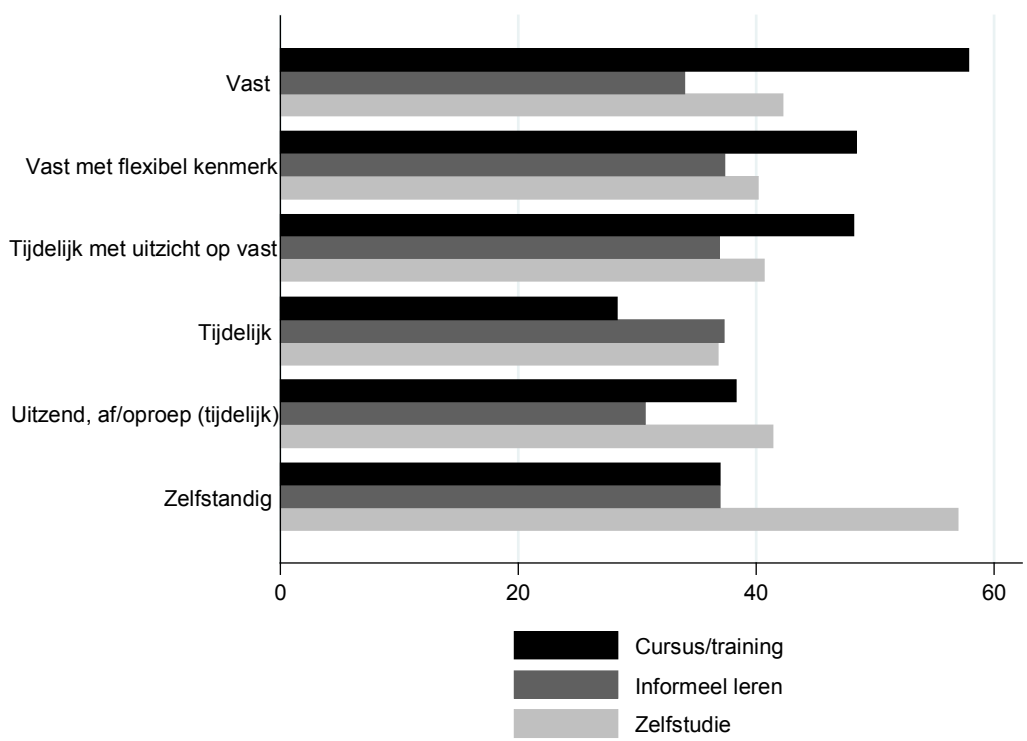

1) Percentage deelname voor cursus/training en zelfstudie, en percentage van de werktijd voor informeel leren

\section{Informeel leren}

Wat betreft het deel van de werktijd dat aan informeel leren besteed wordt, zijn de verschillen tussen werkenden met een flexibel of vast contract aanzienlijk kleiner dan bij het volgen van formele training. ${ }^{24}$ Gemiddeld besteden werkenden ongeveer een derde van hun werktijd aan activiteiten waarvan zij kunnen leren. Werkenden in vaste dienst besteden $34 \%$ van hun werktijd aan taken waarvan zij kunnen leren. Uitzend-, afroep- en

\section{De werktijd die aan informeel leren wordt besteed wijkt niet af tussen contractvormen} oproepkrachten besteden het kleinste

24. De in hoofdstuk I genoteerde correlatie tussen cursusdeelname en informeel leren is significant zowel voor personen met een vast contract als voor flexwerkers. 
deel van hun werktijd (31\%) aan informele leeractiviteiten. Werkenden met andere contractvormen besteden ongeveer $37 \%$ van hun werktijd aan informeel leren. Wanneer er gecontroleerd wordt voor geslacht, leeftijd en opleidingsniveau dan blijkt de flexibiliteit van het contract geen significante rol te spelen voor de mate waarop men tijdens het werk leert.

\section{Zelfstudie}

Evenals het geval was voor informeel leren, blijkt ook de tijd die besteed wordt aan zelfstudie weinig af te wijken tussen de verschillende onderscheiden contractvormen. De enige uitzondering hierop vormen de zelfstandigen, die vaker aan zelfstudie doen dan degenen die in loondienst werkzaam zijn. Van de zelfstandigen doet $57 \%$ aan zelfstudie, tegenover slechts $42 \%$ van de werkenden met een vast dienstverband. Zelfstandigen die aan zelfstudie doen besteden daar boven-

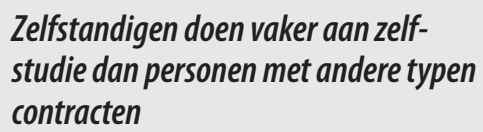
werkenden met een tijdelijk contract blijken gemiddeld het minst vaak aan zelfstudie te doen $(37 \%)$. Als ze het doen dan besteden ze daar echter wel meer tijd aan: gemiddeld 4 uur per maand. Tijdelijke krachten en uitzend-, afroep- en oproepkrachten doen ongeveer even vaak aan zelfstudie als werkenden in vaste dienst (4I\%), maar tijdelijke krachten besteden daar per maand gemiddeld 4 uur aan, terwijl uitzend-, afroep- en oproepkrachten er gemiddeld slechts 2 uur aan besteden. Nadat er gecontroleerd wordt voor geslacht, leeftijd en opleidingsniveau van werkenden, blijft echter alleen de hogere deelname aan zelfstudie door zelfstandigen nog significant te zijn.

\subsection{Scholing van flexwerkers in tijd en geld}

Tabel 2.I laat zien dat er verschillen bestaan tussen flexwerkers en medewerkers met (kenmerken van) een vast contract als het gaat om wie de cursus financiert. De cursusdeelname van werkenden met een vast contract of een vast contract met flexibele kenmerken wordt vaker dan gemiddeld betaald door de werkgever. Bij 91\% van de werknemers in vaste dienst wordt de cursus of training door de werkgever betaald. Bij werknemers met een vast contract die elders gedetacheerd worden betaalde de werkgever zelfs vrijwel alle

Werkgevers betalen vaker voor cursussen van werknemers in vaste dienst cursussen (99\%). Bij werkenden met een tijdelijk contract met uitzicht op een vast contract en tijdelijke krachten betaalde de werkgever de cursus voor $83 \%$ van de werknemers. Onder uitzend-, afroep- en oproep- 
krachten blijken werkgevers voor driekwart van de cursussen te betalen. Hoewel werkgevers minder vaak betalen voor cursussen van flexkrachten blijkt uit de cijfers in tabel 2.I dat ze dat toch geregeld doen. Dit kan komen doordat werkgevers de scholing gebruiken om de kwaliteit van hun dienst of productie te garanderen en/of als screeningsinstrument bij het selecteren van arbeidskrachten. Zo laat Autor (200I) zien dat bedrijven in de uitzendbranche scholing bieden aan hun uitzendkrachten positieve selectie tot stand brengen doordat werknemers die bovengemiddeld bekwaam zijn eerder kiezen voor een baan met mogelijkheden om te leren. Bovendien geeft de auteur aan dat er door het bieden van scholing informatie wordt verkregen over het productiviteitspotentieel van de werknemers, bijvoorbeeld door de training te koppelen aan het testen van de vaardigheden van werknemers.

Tabel 2.1

Wie betaalt de scholing en wie neemt het initiatief?, naar contractvorm, 2013

\begin{tabular}{|c|c|c|c|c|c|c|}
\hline & \multicolumn{3}{|c|}{ Wie betaalde de kosten van scholing? } & \multicolumn{3}{|c|}{ Wie nam initiatief tot scholing? } \\
\hline & $\begin{array}{l}\text { Zelf } \\
\%\end{array}$ & $\begin{array}{c}\text { Werkgever } \\
\%\end{array}$ & $\begin{array}{c}\text { Anders }^{1)} \\
\%\end{array}$ & $\begin{array}{l}\text { Zelf } \\
\%\end{array}$ & $\begin{array}{c}\text { Werkgever } \\
\%\end{array}$ & $\begin{array}{c}\text { Beiden } \\
\%\end{array}$ \\
\hline Vast & 6 & 91 & 3 & 35 & 40 & 26 \\
\hline Vast met flexibele kenmerken & 1 & 99 & 0 & 19 & 20 & 61 \\
\hline Tijdelijk met uitzicht op vast & 12 & 83 & 5 & 22 & 57 & 22 \\
\hline Tijdelijk & 13 & 83 & 4 & 38 & 46 & 17 \\
\hline Uitzend-, afroep-, of oproepcontract & 6 & 77 & 17 & 22 & 44 & 34 \\
\hline Zelfstandige & 71 & $12^{2)}$ & 16 & 82 & $10^{2)}$ & 8 \\
\hline
\end{tabular}

Zelfstandigen draaien zelf vaak op voor de kosten van hun scholing: bij I2\% van de zelfstandigen die een cursus of training volgden werd deze door de opdrachtgever betaald. Zeven op de tien zelfstandigen betaalden de cursusdeelname zelf; bij de werknemers in vaste dienst was dit slechts $6 \%$. Zelfstandigen nemen, zoals verwacht mag worden, vaak het initiatief voor hun eigen scholing: in slechts $18 \%$ van de gevallen werd de scholing gevolgd op initiatief van de opdrachtgever of vanuit een gezamenlijk initiatief van de opdrachtgever en de zelfstandige zelf.

Wie het initiatief neemt voor het volgen van scholing verschilt duidelijk naar de aard van het arbeidscontract. Voor tijdelijke krachten met uitzicht op een vast contract komt het initiatief relatief vaak van de werkgever. Dit bevestigt het beeld dat voor deze werknemers het behalen van een cursus een voorwaarde kan zijn voor het omzetten van hun tijdelijke aanstelling naar een vast dienstverband. Ook bij tijdelijke krachten en uitzend-, afroep-, of oproepkrachten wordt de cursus echter opmerkelijk vaak gevolgd op initiatief van de werkgever.

Tabel C.I in bijlage C illustreert de verschillen naar opleidingsniveau en contractvorm met betrekking tot wie de kosten van scholing draagt en wie het initiatief tot scholing genomen heeft. Het laat zien dat laagopgeleiden in flexbanen minder vaak een door 
de werkgever bekostigde scholing krijgen dan hoger opgeleiden, maar dat het initiatief tot scholing vaker van de werkgever komt.

Hoewel werkenden overwegend cursussen volgen in werktijd, zijn er wel verschillen tussen de verschillende contractvormen. Werkenden met een uitzend-, afroep- en oproepcontract volgen hun cursussen voor $57 \%$ onder werktijd. Bij andere contactvormen is dit aanzienlijk hoger: $73 \%$. Zelfstandigen volgen scholing over het algemeen in hun eigen tijd: slechts $38 \%$ van de tijd die zij aan het volgen van cursussen besteden vindt onder werktijd plaats.

\subsection{Motieven van flexwerkers om te leren}

Aan werkenden die in de afgelopen twee jaar een cursus of training hebben gevolgd is gevraagd wat hun motieven waren om een cursus te volgen. Hierbij konden zij antwoorden aan de hand van een zeven-puntsschaal die oploopt van I) helemaal niet mee eens tot en met 7) helemaal mee eens. In tabel 2.2 wordt het percentage (helemaal) mee eens gerapporteerd; dat wil zeggen het percentage werkenden dat 5, 6 of 7 antwoorde op de schaal. Er kunnen meerdere motieven hebben gespeeld bij het volgen van een cursus.

Uit hoofdstuk I kwamen de belangrijkste redenen om een cursus te gaan volgen naar voren: omdat deze verplicht is, voor het realiseren van loopbaandoelstellingen of omdat kennis en ervaring onvoldoende waren. Tabel 2.2 somt een breed scala aan motieven voor cursusdeelname op die werkenden in 2013 noemden en laat zien of deze motieven verschillen tussen de onderscheiden contractvormen. Ongeacht het soort contract, komt het verplichte karakter van de cursus naar voren bij alle groepen werknemers als de belangrijke reden voor het volgen van een cursus. Bij zelfstandigen is het verhogen van de kwaliteit veruit de belangrijkste drijfveer voor het volgen van cursussen.

\section{Vaste contracten}

Werkenden met een vast contract volgen vergeleken met werkenden met een flexibel contract relatief vaak een cursus omdat er op hun werk een nieuwe manier van werken is geïntroduceerd. $\mathrm{Zij}$ volgen daarentegen juist minder vaak een cursus met als doel hun kans op een baan in algemene zin te vergroten.

Vaste contracten: relatief vaak op cursus om nieuwe manier van werken eigen te maken 


\section{Vaste contracten met flexibele kenmerken}

Aan de cursusdeelname van personen met een vast contract dat flexibele kenmerken vertoont, liggen diverse redenen ten grondslag. In vergelijking met werknemers met een andere contractvorm geven zij vooral vaker aan dat zij de cursus volgden omdat hun kennis en ervaring onvoldoende waren voor het werk dat zij doen, dat de cursus hen hielp bij het realiseren van hun loopbaandoelen, dat zij nieuwe taken hebben gekregen of gaan krijgen, dat zij de cursus gevolgd hebben om meer waardering van hun leidinggevende te krijgen, of omdat de cursus verplicht was. In vergelijking met werkenden met andere soorten contracten volgen zij daarentegen aanzienlijk minder vaak cursussen met het oog op het vergroten van hun baankans.

\section{Tijdelijke contracten met uitzicht op vast contract}

Medewerkers in tijdelijke loondienst met uitzicht op een vast contract volgen vaker een cursus om hun kans op een vast contract te vergroten dan andere werknemers. Wat verder opvalt bij medewerkers met dit type contract is dat drie motieven duidelijk minder vaak genoemd worden dan door cursusdeelnemers met andere typen contracten. Zo volgen zij minder vaak een cursus omdat er een nieuwe manier van werken is geïntroduceerd, om hun loopbaandoelen te realiseren, of omdat zij nieuwe taken gekregen hebben of gaan krijgen.

\section{Tijdelijke contracten (zonder uitzicht op vast contract)}

Bij de motieven voor de cursusdeelname van werkenden met een tijdelijk contract valt het vooral op dat er enkele motieven zijn die duidelijk vaker dan gemiddeld genoemd worden: het vergroten van de baankans $(39 \%)$ en het realiseren van loopbaandoelen $(34 \%)$. Dit suggereert dat tijdelijke krachten zich vooral scholen met het oog op hun inzetbaarheid op de externe arbeidsmarkt. Daarentegen spelen veel andere motieven bij werknemers met dit soort contracten duidelijk

Belangrijke motieven bij flexibele contracten zijn 0.a. het vergroten van de baankans en de kans op een vaste baan minder vaak een rol bij de beslissing scholing te volgen: onvoldoende kennis en vaardigheden, nieuwe manieren van werken en nieuwe taken, promotiekansen, een hoger loon en het krijgen van waardering van hun leidinggevende. Dit illustreert de geringe binding die deze tijdelijke medewerkers hebben met de organisatie waar ze werkzaam zijn.

\section{Uitzend-, afroep-en oproepcontract}

Bij de cursusdeelname van uitzend-, afroep- en oproepkrachten spelen verschillende redenen een belangrijke rol. In vergelijking met personen met andere contractvormen 
nemen zij relatief vaak deel aan cursussen om zo hun baankans te vergroten, maar vooral om de kans op een vaste baan te vergroten. Verder speelt voor deze groep vaker dan gemiddeld een rol dat ze cursus volgen omdat ze nieuwe taken hebben gekregen of dat zij de cursus eenvoudigweg hebben gevolgd omdat deze verplicht was.

\section{Zelfstandigen}

Zelfstandigen (voornamelijk zelfstandigen zonder personeel) vormen een groep op zich. Dit komt omdat zij niet zoals alle andere groepen werkenden een arbeidscontract hebben. Daarom zijn bepaalde motieven niet aan deze groep voorgelegd, terwijl andere motieven die specifiek op deze groep van toepassing kunnen

Het verbeteren van de kwaliteit is veruit het belangrijkste motief voor de cursusdeelname van zelfstandigen zijn juist wel aan hen zijn voorgelegd. Meest in het oog springend is hierbij dat niet minder dan driekwart van de zelfstandigen een cursus volgt om meer kwaliteit te kunnen leveren. Daarnaast blijken zelfstandigen vaak aan cursussen deel te nemen met het oog op het verhogen van hun omzet $(38 \%)$, of om te leren hoe zij nieuwe klanten kunnen aantrekken (43\%). Ook gebruiken zij de cursus vaker om hun loopbaandoelen te realiseren. Zelfstandigen die er uit eigen beweging voor kiezen om op eigen benen te staan zijn doorgaans minder geïnteresseerd in het bemachtigen van een vaste baan. Dit motief speelt dan ook vrijwel nooit een rol bij de beslissing om een training te gaan volgen. Ook volgen zelfstandigen minder vaak cursussen omdat zij nieuwe taken hebben gekregen. Tot slot volgen zij duidelijk minder vaak dan andere werkenden een cursus omdat deze verplicht is.

Werkenden die zelf voor hun cursus hebben betaald, geven vaker aan dat ze de cursus hebben gevolgd om hun kansen op een andere baan te vergroten. Daarentegen geven zij minder vaak aan dat ze de cursus zijn gaan volgen omdat er nieuwe manieren van werken zijn geïntroduceerd op het werk, in verband met nieuwe taken op het werk, als blijk van waardering voor goed functioneren of omdat de cursus verplicht was. Bij dergelijke motieven ligt het meer voor de hand dat de werkgever voor de kosten van de cursus opdraait. Er zijn echter wat dit betreft geen verschillen tussen werkenden met een vaste aanstelling en werkenden met een flexibele aanstelling. 
Tabel 2.2

Motieven voor scholingsdeelname, percentage (helemaal) meen eens, naar contractvorm, 2013')

\begin{tabular}{|c|c|c|c|c|c|c|}
\hline & Vast & $\begin{array}{l}\text { Vast met } \\
\text { flexibele } \\
\text { kenmerken }\end{array}$ & $\begin{array}{c}\text { Tijdelijk met } \\
\text { uitzicht op } \\
\text { vast }\end{array}$ & Tijdelijk & $\begin{array}{l}\text { Uitzend-, } \\
\text { afroep-, of } \\
\text { oproep- } \\
\text { contract }\end{array}$ & Zelfstandige \\
\hline & $\%$ & $\%$ & $\%$ & $\%$ & $\%$ & $\%$ \\
\hline Kennis/ervaring onvoldoende & 32 & 41 & 42 & 21 & 32 & 30 \\
\hline Baankans vergroten & 23 & 19 & 33 & 39 & 37 & 18 \\
\hline Grotere kans vaste baan & 11 & 25 & 25 & 14 & 34 & 3 \\
\hline Nieuwe manier van werken & 25 & 18 & 13 & 7 & 23 & 23 \\
\hline Realiseren loopbaandoelen & 31 & 37 & 25 & 34 & 32 & 49 \\
\hline Promotie kunnen maken & 15 & 9 & 12 & 2 & 16 & - \\
\hline Als waardering voor goed functioneren & 12 & 11 & 18 & 17 & 21 & - \\
\hline Hoger inkomen & 10 & 11 & 10 & 6 & 9 & 19 \\
\hline Nieuwe taken gekregen & 28 & 48 & 20 & 11 & 42 & 20 \\
\hline Waardering krijgen van leidinggevende & 7 & 17 & 7 & 0 & 5 & - \\
\hline Cursus was verplicht & 41 & 50 & 47 & 43 & 47 & 21 \\
\hline Verhogen omzet & - & - & - & - & - & 38 \\
\hline Andere soorten klanten & - & - & - & - & - & 43 \\
\hline $\begin{array}{l}\text { Verhogen kwaliteit } \\
\text { 1) Niet alle motieven in de tab } \\
\text { zijn niet voorgelegd aan we } \\
\text { motieven alleen van toepassi } \\
\text { king op zelfstandigen kunne } \\
\text { volgen van een cursus. }\end{array}$ & $\begin{array}{l}\text { zijn } \\
\text { ebb }\end{array}$ & $\begin{array}{l}\text { - } \\
\text { alle respc } \\
\text { let de des } \\
\text { zelfstandi } \\
\text { Er kunner }\end{array}$ & $\begin{array}{l}\text { - } \\
\text { denten vo } \\
\text { etreffende } \\
\text { en, terwijl a } \\
\text { meerdere r }\end{array}$ & $\begin{array}{l}\text { - } \\
\text { gelegd } \\
\text { ontract } \\
\text { dere mo } \\
\text { tieven }\end{array}$ & $\begin{array}{l}\text { e motiev } \\
\text { m. Zo ku } \\
\text { ben juist } \\
\text { bben ges }\end{array}$ & $\begin{array}{l}76 \\
\text { met een - } \\
\text { nen enkele } \\
\text { een betrek- } \\
\text { eeld bij het }\end{array}$ \\
\hline
\end{tabular}

\subsection{Flexwerkers en leerzame taken op het werk}

Gemiddeld besteedden werkenden in 2013 ruim een derde (35\%) van hun werktijd aan taken waarvan zij kunnen leren. Er zijn op dit punt geen significante verschillen tussen de onderscheiden contractvormen (zie figuur 2.2). Zoals bleek uit hoofdstuk I (figuur I.7) leren werkenden in algemene zin het meest van nieuwe en uitdagende werkzaamheden en het minst van alledaagse routinewerkzaamheden. In deze paragraaf wordt voor de negen onderscheiden taken bekeken in welke mate werkenden met verschillende soorten contracten hiervan leren. Dit gebeurt aan de hand van een vijfpuntsschaal die oploopt van I 'erg weinig' tot 5 'erg veel'. De hieronder gepresenteerde bevindingen zijn gebaseerd op regressieanalyses waarin gecontroleerd wordt voor geslacht, leeftijd en opleidingsniveau, en waarbij werknemers met een vast contract de referentiecategorie vormen.

Het meest in het oog springt dat werknemers met een tijdelijk contract met uitzicht op een vaste aanstelling van verschillende taken significant meer leren dan personen met een ander type contract. Zij leren meer van (alledaagse) routinematige werkzaamheden, vergaderingen c.q. overleggen, het lezen van documenten en het maken van 
berekeningen. Dit geldt ook als wij controleren voor verschillen naar geslacht, leeftijd en opleiding. Dit wijst er op dat deze tijdelijke krachten meer inspanningen leveren om een vast contract te kunnen krijgen. Ook leren flexwerkers significant meer dan vaste medewerkers wanneer zij samenwerken met meer ervaren collega's. Dit geldt zowel voor uitzend-, afroep- en oproepkrachten, als werknemers met een tijdelijk contract zonder uitzicht op een vast contract. Tot slot leren werknemers met een tijdelijk contract zonder uitzicht op een vast contract, significant meer dan werknemers met andere contractvormen wanneer zij berekeningen maken. Vergeleken met werknemers in vaste dienst leren zelfstandigen minder van (alledaagse) routinewerkzaamheden, werkzaamheden waarbij zij voor uitdagingen staan die zij moeten oplossen en werkzaamheden die zij nog niet eerder hebben gedaan.

\subsection{Maken salaris en het leren op het werk flexibele banen aantrekkelijker?}

In de 2013 ROA Levenslang Leren Enquête is met behulp van een vignetanalyse onderzocht in welke mate bepaalde kenmerken van een baan aantrekkelijk of juist onaantrekkelijk worden gevonden. In het vignet moesten respondenten zich voorstellen dat zij niet langer in hun eigen baan kunnen blijven werken en dat zij een keuze moeten maken tussen twee alternatieve banen. ${ }^{25}$ Deze keuze moesten respondenten drie keer maken voor drie verschillende combinaties van banen. De banen verschillen van elkaar op de volgende gerandomiseerde kenmerken:

- Aard van het contract:

Tijdelijk voor 2 jaar zonder uitzicht op een vast contract,

Tijdelijk, met 20\% kans op een vast contract na 2 jaar,

Tijdelijk, met 50\% kans op een vast contract na 2 jaar,

Tijdelijk, met $80 \%$ kans op een vast contract na 2 jaar,

Vast contract.

- Het salaris: ${ }^{26}$

Loon is hetzelfde als uw huidige loon,

Loon is $5 \%$ hoger dan uw huidige loon,

Loon is IO\% hoger dan uw huidige loon,

Loon is $5 \%$ lager dan uw huidige loon,

Loon is IO\% lager dan uw huidige loon.

- De mate waarin men zelf de werktijden kan inrichten:

Helemaal niet,

In beperkte mate,

Helemaal.

25. Aan niet-werkenden is gevraagd een keuze te maken tussen twee aangeboden banen

26. Voor niet-werkenden zijn iets andere categorieën gebruikt. Loon is gemiddeld voor iemand met uw opleidingsachtergrond, loon is $5 \%$ hoger dan gemiddeld voor iemand met uw opleidingsachtergrond, loon is IO\% hoger dan gemiddeld voor iemand met uw opleidingsachtergrond, loon is $5 \%$ lager dan gemiddeld voor iemand met uw opleidingsachtergrond, loon is Io\% lager dan gemiddeld voor iemand met uw opleidingsachtergrond. 
- Het percentage van de werktijd dat men in die baan besteed aan leerzame taken:

$$
\begin{aligned}
& 5 \%, \\
& \text { IO\%, } \\
& 20 \%, \\
& 40 \% .
\end{aligned}
$$

Met deze opzet kan worden nagegaan in welke mate mensen een afruil maken tussen verschillende kenmerken van banen. Zo kan men bijvoorbeeld de voorkeur hebben voor een vaste baan boven een tijdelijke baan, maar is deze voorkeur minder sterk naarmate de tijdelijke baan meer mogelijkheden biedt om informeel te leren ${ }^{27}$ of een hoger salaris biedt.

\section{Figuur 2.3}

Kans dat men voor baan kiest naar de aard van het contract, procenten

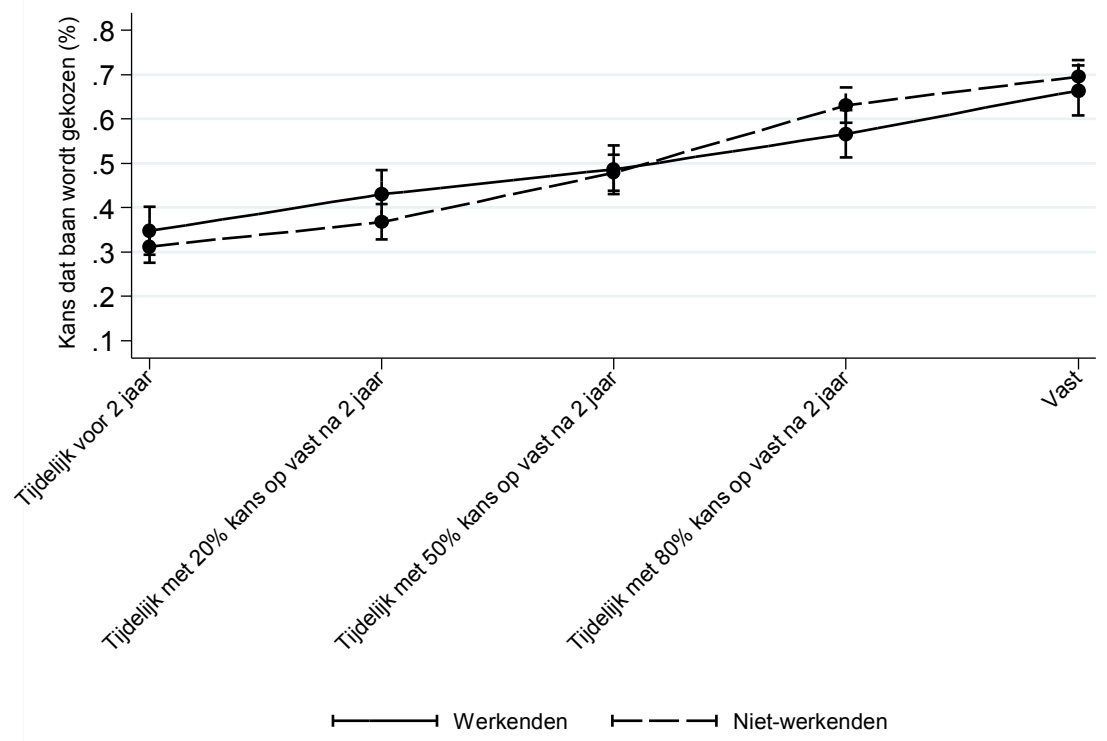

Figuur 2.3 laat voor werkenden en niet-werkenden zien hoe groot de kans is dat ze een baan kiezen met een bepaald arbeidscontract. Deze kans is berekend aan de hand van een econometrisch model waarbij voor de kenmerken van de baan uitgegaan wordt waar men in beperkte mate de mogelijkheid heeft om de eigen werktijd in te richten, waar men $20 \%$ van de werktijd besteedt aan leerzame taken en waar het loon hetzelfde is als het huidige loon. De figuur laat zien dat voor zowel werkenden als niet-

27. Zoals in hoofdstuk I bleek, is informeel leren een belangrijke bron van nieuwe kennis en vaardigheden. 
werkenden de kans dat men een van de twee alternatieve banen kiest stijgt naarmate de kans op een vaste aanstelling groter is. De verschillen tussen werkenden en nietwerkenden zijn op dit punt niet significant. De kans dat men de tijdelijke baan kiest (31\% voor werkenden) is ruim de helft lager dan de kans dat men voor de vaste baan kiest (70\% voor werkenden).

\section{Keuze voor tijdelijk werk bij meer informeel leren}

\section{Figuur 2.4}

Kans dat men voor baan kiest naar de aard van het contract en het percentage van de werktijd besteed aan informeel leren

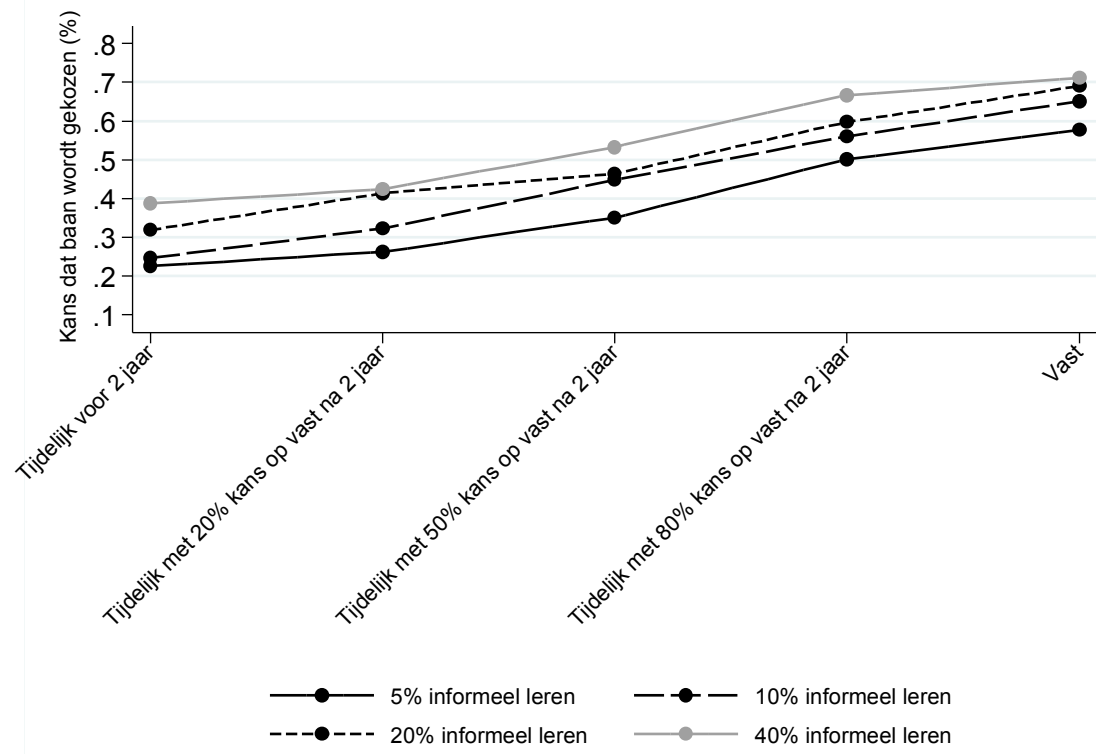

In figuur 2.4 wordt de kans dat men voor een baan met een bepaald contract kiest gerelateerd aan het percentage van de werktijd dat besteed wordt aan leerzame taken. Naarmate dat percentage hoger ligt is men eerder bereid de baan te kiezen, ook wanneer het een tijdelijke baan betreft zonder enig uitzicht op een vaste aanstelling. De figuur laat ook zien dat een verhoging van het informeel leren in de baan de kans verdubbelt dat iemand een

Informeel leren in een tijdelijke baan compenseert niet voor het tijdelijke karakter van de baan tijdelijke baan voor twee jaar kiest, maar dat zo'n verhoging veel minder effect heeft op de voorkeur voor een vaste baan. Met andere woorden: er is meer informeel leren nodig om een tijdelijke baan aantrekkelijk te maken. Een stijging van de mogelijkheden tot informeel leren tijdens het werk van $5 \%$ naar $40 \%$ van de werktijd vergroot de kans dat men voor de tijdelijke 
baan kiest van 22\% naar 39\%. Dat is echter altijd minder dan de gemiddelde voorkeur voor een vaste baan waar slechts $5 \%$ van de werktijd besteed wordt aan leerzame taken (58\%). Wij kunnen hieruit concluderen dat meer leerzame taken tijdelijk werk aantrekkelijker maken, maar dat dit onvoldoende is om tijdelijke banen een echt aantrekkelijk alternatief te maken voor een vaste baan.

\section{Keuze voor tijdelijk werk bij meer loon}

Figuur 2.5 laat zien dat men eerder bereid is een tijdelijke baan aan te nemen naarmate deze een hogere beloning biedt. De kans dat men een tijdelijke baan zou kiezen verdubbelt van $25 \%$ naar $5 \mathrm{I} \%$ als het loon stijgt van IO\% onder iemands huidige loon naar IO\% boven het huidige loon. Ter vergelijking: de kans dat men de vaste baan zou kiezen met een beloning

\section{Een hogere beloning lijkt te compen- seren voor het gebrek aan zekerheid in een baan}

die IO\% lager ligt dan het huidige loon is $59 \%$. Dit wijst er dus op dat er sprake is van een afruil tussen beloning en het tijdelijk karakter van een baan: een hogere beloning lijkt werknemers te compenseren voor het gebrek aan zekerheid in de baan.

\section{Figuur 2.5}

Kans dat men voor baan kiest naar de aard van het contract en de beloning

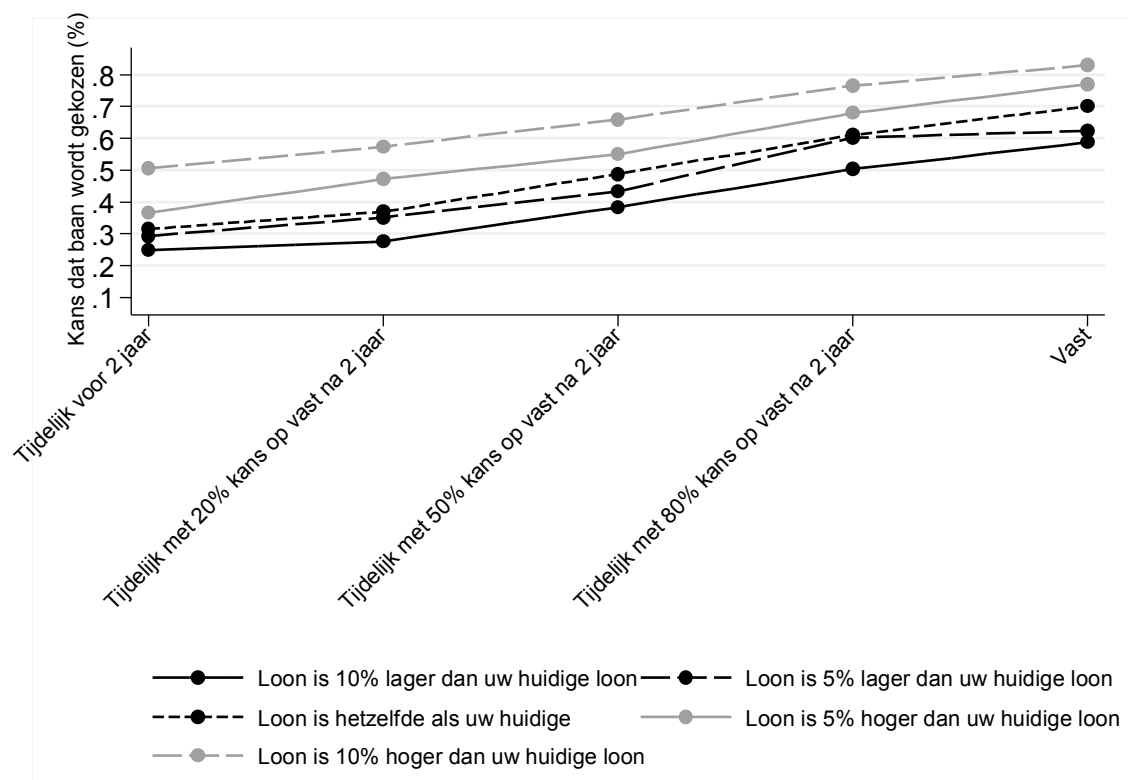




\section{Huidig contract en risicoattitude}

In een aanvullende analyse is onderzocht in welke mate iemands risicoattitude van invloed is op de bereidheid om een baan te kiezen met een tijdelijk contract. Voor werkenden in loondienst zijn het wel of niet hebben van een vaste aanstelling in de huidige baan en de kans op een vaste aanstelling in het vignet niet gerelateerd aan de keuze die werknemers maken tussen de twee banen. Dit betekent dat werknemers met een vast dienstverband niet systematisch kiezen voor banen met een grotere kans op een vast dienstverband dan werknmers met een flexibele aanstelling.

Bij gelijke baankenmerken zijn werknemers die meer risico's durven te nemen ook eerder bereid om een baan met een tijdelijke aanstelling te kiezen. Dit is in lijn met eerdere studies die laten zien dat er een correlatie is tussen risicobereidheid en de kans dat iemand werkzaam is in

Mensen die meer risico durven te nemen kiezen vaker voor een tijdelijk contract

een tijdelijke baan (Di Mauro en Musumeci 20II) en de kans dat iemand zelfstandig ondernemer is (Ekelund et al. 2005). 


\section{Formeel en informeel leren door oudere werkenden}

De menselijk-kapitaaltheorie stelt dat investeringen in scholing gezien kunnen worden binnen een raamwerk dat analoog is aan dat van investeringen in fysieke kapitaalgoederen. Bepalend bij de keuze om wel of niet in menselijk kapitaal te investeren is de lengte van de toekomstige periode waarin men verwacht rendement te kunnen halen uit een dergelijke investering (Fouarge en De Grip 20I4). Omdat de maximale tijdshorizon waarin investeringen in menselijk kapitaal kunnen renderen, gelijk is aan de tijd tot de (verwachte) pensioenleeftijd, zullen werknemers (en hun werkgevers) minder in hun kennis en vaardigheden investeren naarmate zij ouder worden.

Mede als gevolg van de afschaffing van de vroegere VUT-regelingen en de afbouw van de prespensioenregelingen is de arbeidsparticipatie onder ouderen de afgelopen jaren flink toegenomen (Euwals et al. 20I0). De bruto arbeidsparticipatie onder 55-64 jarigen is gestegen van $25,5 \%$ in 1993 (een historisch dieptepunt) tot $59,6 \%$ in 2013 , en de gemiddelde leeftijd van werknemers bij pensionering is intussen bijna 64 jaar (Arts en Otten 20I4). Als gevolg van de verhoging van de AOW-leeftijd kan een verdere stijging van de pensioenleeftijd worden verwacht (De Grip et al. 2013). Dit roept de vraag op hoe het gesteld is met het menselijk kapitaal van oudere werknemers: houden zij hun kennis voldoende op peil, en hoe doen zij dat? Dit zijn de vragen die in dit hoofdstuk beantwoord worden. Gelet op de focus van dit hoofdstuk wordt in tegenstelling tot hoofdstuk I gekeken naar personen tot en met 70 jaar.

In paragraaf 3.I gaan wij in op de ontwikkeling van het leren door ouderen in het algemeen. Paragraaf 3.2 kijkt naar de verschillen naar contractvorm per leeftijdsgroep. Ten slotte belichten we in paragraaf 3.3 in hoeverre het leren door ouderen gerelateerd is aan technologische en organisatorische ontwikkelingen, iemands motivatie en het door de werkgever gevoerde HR beleid. 


\subsection{Ontwikkeling in het leren van ouderen}

In hoofdstuk I is al een schets gegeven van de ontwikkeling van de scholingsdeelname naar leeftijd. Daaruit bleek dat de scholingsdeelname onder ouderen lager ligt dan onder jongeren, maar dat de kloof tussen jong en oud tussen 2004 en 2013 is afgenomen door een stijging van de scholingsdeelname door ouderen. Dit illustreert figuur 3.I nogmaals vanuit het perspectief van de opeenvolgende leef-
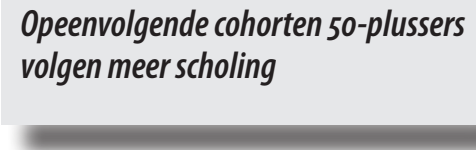
tijdscohorten. De figuur laat zien dat de deelname aan cursussen en trainingen door 60-jarigen in het geboortecohort 1950I954 hoger ligt dan voor het cohort I945-1949, dat op haar beurt weer meer scholing volgde dan het cohort I940-I944.

Figuur 3.1

Ontwikkeling van formeel leren naar geboortecohort, 2004-2013

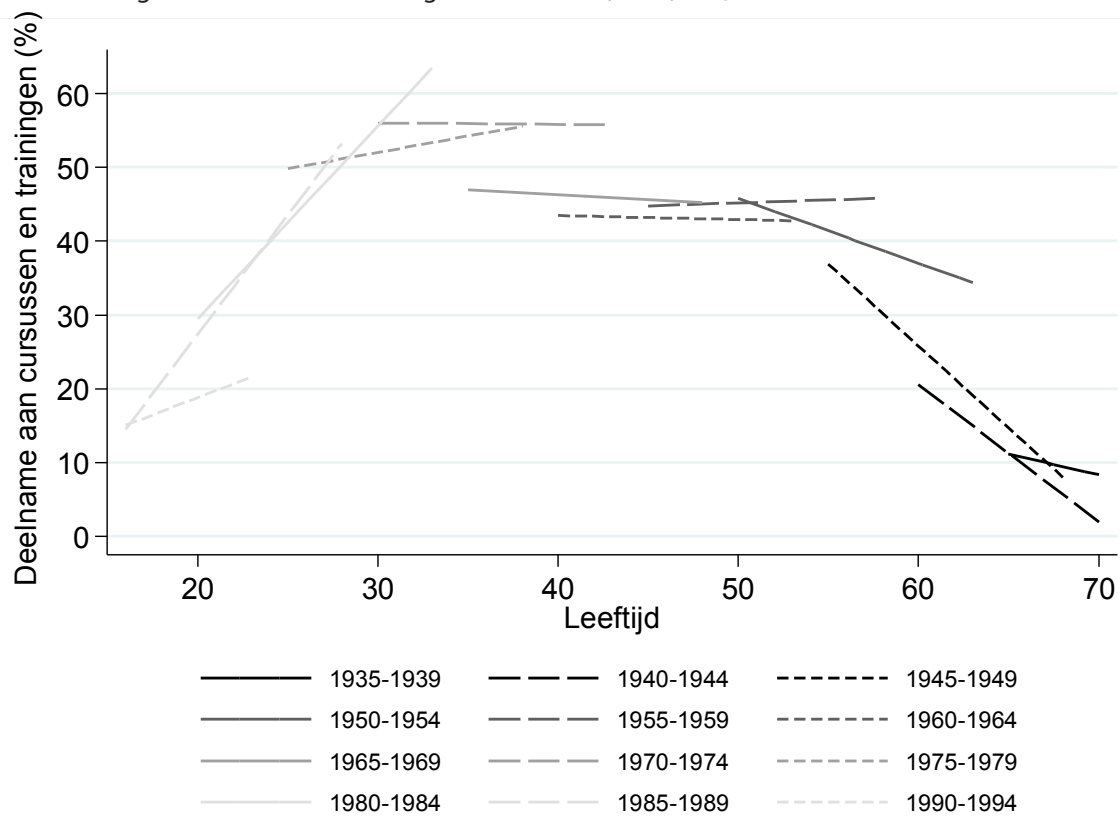

Een vergelijkbaar patroon zien we wanneer er gekeken wordt naar het informeel leren van de werkenden. Figuur 3.2 laat zien dat opeenvolgende cohorten van werkenden meer taken hebben gekregen waarvan ze leren, al is de ontwikkeling onder de 45-plussers minder eenduidig. Ten slotte laat figuur 3.3 zien dat de kennisontwikkeling van 45-plussers zich gunstig ontwikkelt over de opeenvolgende cohorten. Uit de data blijkt dat de deelname aan formele scholing en het informeel leren tijdens het werk positief correleert met de kennisontwikkeling. Dit gaat ook op voor 45-plussers: de 
correlatie (na controle voor geslacht en opleidingsniveau) tussen formeel en informeel leren is niet significant verschillend voor 45 -plussers dan voor jongere werknemers.

\section{Figuur 3.2}

Ontwikkeling van informeel leren onder werkenden naar geboortecohort, 2004-2013

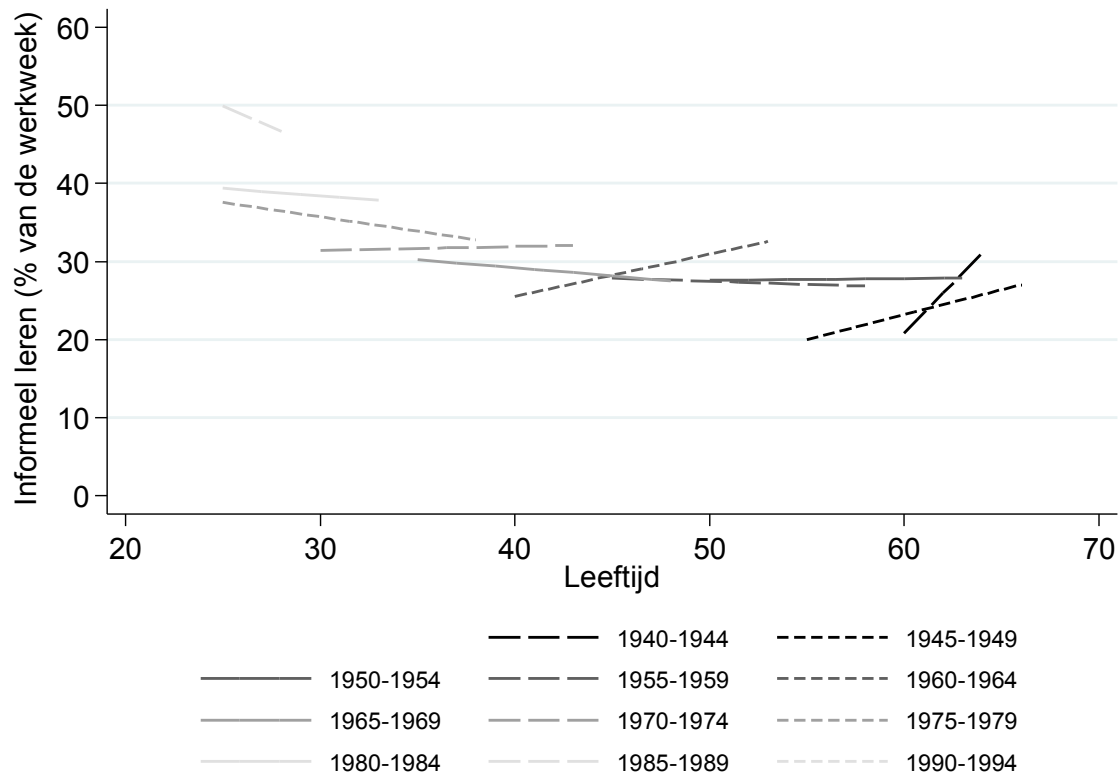

Figuur 3.3

Kennisontwikkeling van werkenden naar geboortecohort, 2004-2013

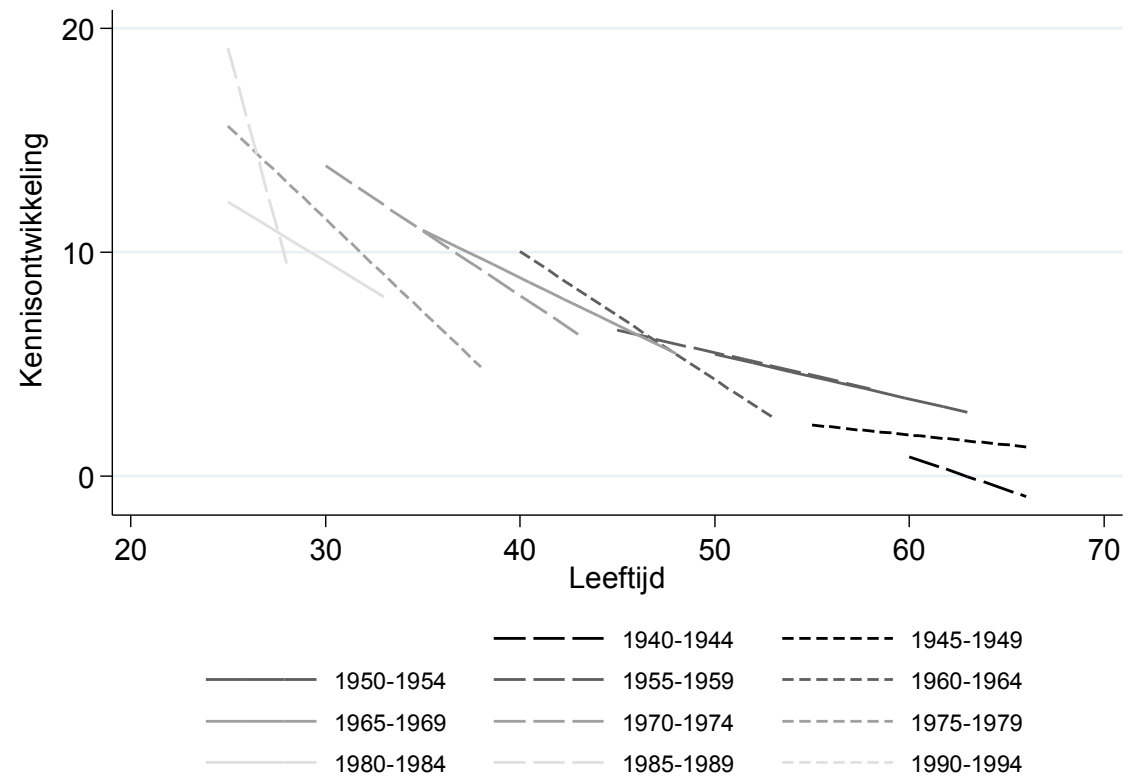


Hoewel 45-plussers minder vaak aan training deelnemen dan jongere werknemers is de intensiteit van de gevolgde cursussen in termen van het aantal dagen dat de cursus duurde niet verschillend van dat van jongeren: in 2013 gaat het om cursussen van ongeveer 3 dagen. ${ }^{28} \mathrm{Wel}$ is het zo dat 45-plussers iets minder uren besteden aan de gevolgde cursus: 16-44 jarigen

Scholing door ouderen draagt bij tot gevoel van employability besteden ongeveer 7 uur per cursusdag. Voor 45-54 en 55-70 jarigen is dat I uur minder. Voor zowel 45-54 als 55-70 jarige werkenden is de deelname aan scholing significant positief gerelateerd aan het gevoel van employability.

Tabel 3.I laat de verschillen naar leeftijd zien over wie het initiatief tot het volgen van scholing heeft genomen en wie de kosten van scholing heeft betaald. 55-plussers geven vaker aan dan 16-44 en 45-54 jarige werkenden dat zij de scholing hebben gevolgd op initiatief van hun werkgever. Naar leeftijd zijn er geen significante verschillen in wie de kosten van scholing betaalt.

\section{Scholing 55-plussers is vaker op initi- atief van de werkgever}

\section{Tabel 3.1}

Initiatief voor volgen van scholing en financiering ervan naar leeftijd, werkenden, 2013

\begin{tabular}{lccc|} 
& $\begin{array}{c}16-44 \text { jaar } \\
\%\end{array}$ & $\begin{array}{c}45-54 \text { jaar } \\
\%\end{array}$ & $\begin{array}{c}55-70 \text { jaar } \\
\%\end{array}$ \\
& & & \\
Initiatief voor scholing: & & & 31 \\
Zelf & 34 & 35 & 47 \\
Werkgever & 35 & 36 & 22 \\
Beide & 31 & 29 & \\
& & & 11 \\
Kosten betaald door: & & & 86 \\
Zelf & 7 & 13 & 3 \\
Werkgever & 88 & 85 & 2 \\
Anders & 5 & &
\end{tabular}

28. Het gaat hier om de mediane duur van cursussen. 
Zoals tabel 3.2 laat zien geven 45-plussers vaker aan dat de kennis en vaardigheden die ze in een cursus of training hebben opgedaan in (zeer) hoge mate bruikbaar zijn in hun huidige werk. Het verschil is echter niet significant wanneer er rekening gehouden wordt met verschillen in geslacht en opleidingsniveau.

Daarentegen geven 45-plussers minder

Scholing 55-plussers is vaker gericht op hun huidige baan vaak aan dat de opgedane kennis en vaardigheden bruikbaar zijn bij andere organisaties in een andere branche. Voor 55-70 jarigen is dit verschil ook significant wanneer er rekening wordt gehouden met verschillen in geslacht en opleidingsniveau.

Gevraagd naar de focus van de gevolgde cursus geeft 52\% van de 55-plussers aan dat deze gericht was op vakspecifieke kennis. Dit is vergelijkbaar met het percentage onder de I6-44 jarigen. 45-54 jarigen geven nog vaker aan (57\%) dat de cursus gericht was op vakspecifieke kennis. De cijfers in dit hoofdstuk laten dus zien dat oudere werknemers minder vaak aan scholing deelnamen, en dat wanneer zij dat wel doen het vaker op initiatief van de werkgever is die dan ook doorgaans betaalt voor een cursus dat gericht is op de inzetbaarheid in de huidige baan.

Tabel 3.2

Bruikbaarheid van de cursus naar leeftijd, 2013

\begin{tabular}{lccc|} 
& $\begin{array}{c}16-44 \text { jaar } \\
\%\end{array}$ & $\begin{array}{c}45-54 \text { jaar } \\
\%\end{array}$ & $\begin{array}{c}55-70 \text { jaar } \\
\%\end{array}$ \\
\hline In huidige werk & 81 & 86 & 86 \\
Bij andere organisatie in zelfde branche & 81 & 77 & 75 \\
\hline Bij andere organisatie in andere branche & 47 & 40 & 35
\end{tabular}

Tabel 3.3 laat voor werkenden zien in welke mate verschillende motieven een rol hebben gespeeld bij het volgen van een cursus. De belangrijkste conclusie daaruit is dat 45-54 jarigen en vooral 55-70 jarigen vaker een cursus of training volgen omdat ze daartoe verplicht worden. Verder blijken oudere werknemers, vergeleken bij jongere werknemers, minder ambitieuze doelen voor ogen te hebben bij het volgen van cursussen. Zo

Ouderen minder ambitieus bij deelname aan cursussen spelen bijvoorbeeld het realiseren van loopbaandoelen, het vergroten van de baankansen en promotiekansen een minder belangrijke rol bij het volgen van cursussen (zie ook Zwick 20II). 
Tabel 3.3

Reden voor het volgen van cursus, werkenden naar leeftijd, 2013

\begin{tabular}{lccc|} 
& $16-44$ jaar & $45-54$ jaar & $55-70$ jaar \\
& $\%$ & $\%$ & $\%$ \\
\hline Cursus verplicht & 34 & 39 & 50 \\
\hline Realiseren loopbaandoelen & 44 & 27 & 20 \\
\hline Kennis/ervaring onvoldoende & 32 & 34 & 34 \\
\hline Nieuwe taken gekregen & 32 & 29 & 30 \\
\hline Nieuwe manier van werken & 21 & 21 & 36 \\
\hline Baankans vergroten & 26 & 17 & 17 \\
\hline Als waardering voor goed functioneren & 17 & 15 & 11 \\
\hline Promotie kunnen maken & 19 & 12 & 7 \\
\hline Hoger inkomen & 14 & 10 & 8 \\
\hline Waardering krijgen van leidinggevende & 7 & 6 & 6
\end{tabular}

\subsection{Leren naar contractvorm en leeftijd ${ }^{29}$}

Figuur 3.4 geeft een overzicht van de cursusdeelname van werkenden in de verschillende leeftijdsgroepen verbijzonderd naar de aard van hun arbeidscontract. Onder werknemers in vaste dienst, maar vooral onder flexwerkers blijkt de deelname aan scholing af te nemen met de leeftijd. Dat is ook het geval bij het informeel leren tijdens het werk (figuur 3.5). Onder zelfstandigen is de deelname aan scholing lager, maar er zijn nauwelijks verschillen in scholingsdeelname tussen de leeftijdsgroepen. Echter ook onder zelfstandigen daalt het informeel leren sterk met de leeftijd.

29. In deze paragraaf wordt evenals in hoofdstuk 2 gebruik gemaakt van cijfers uit het CentERpanel aangevuld met LISS (zie bijlage A). 


\section{Figuur 3.4}

Cursusdeelname door werkenden naar contractvorm en leeftijd, 2013

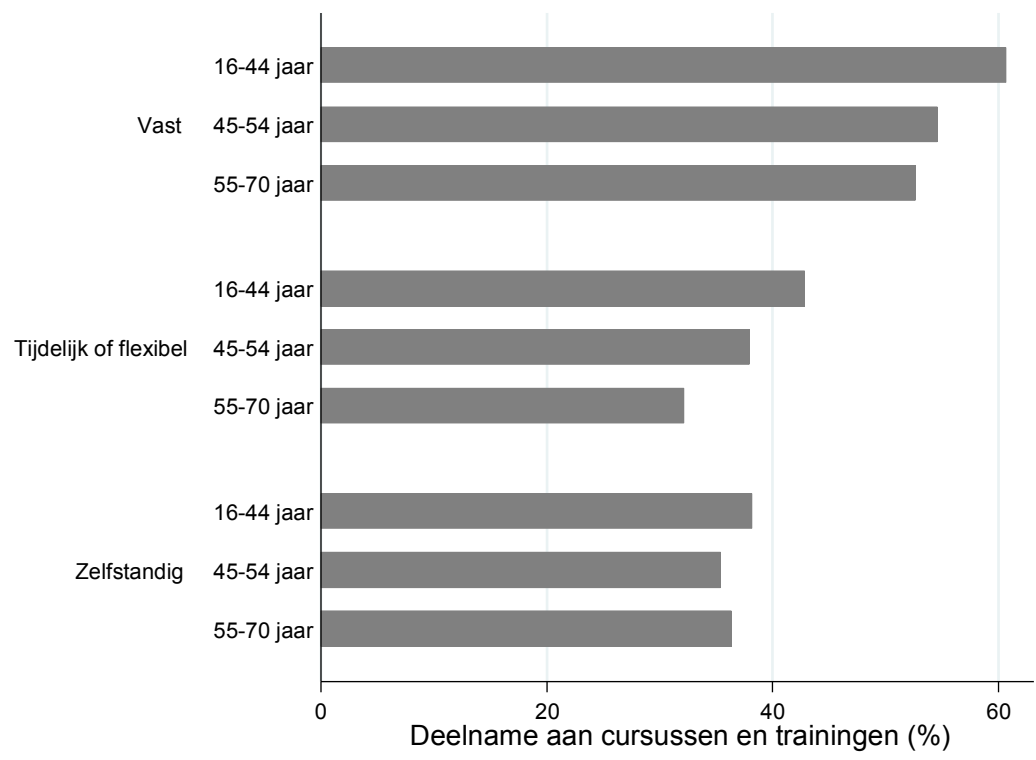

Figuur 3.5

Informeel leren naar contractvorm en leeftijd, 2013

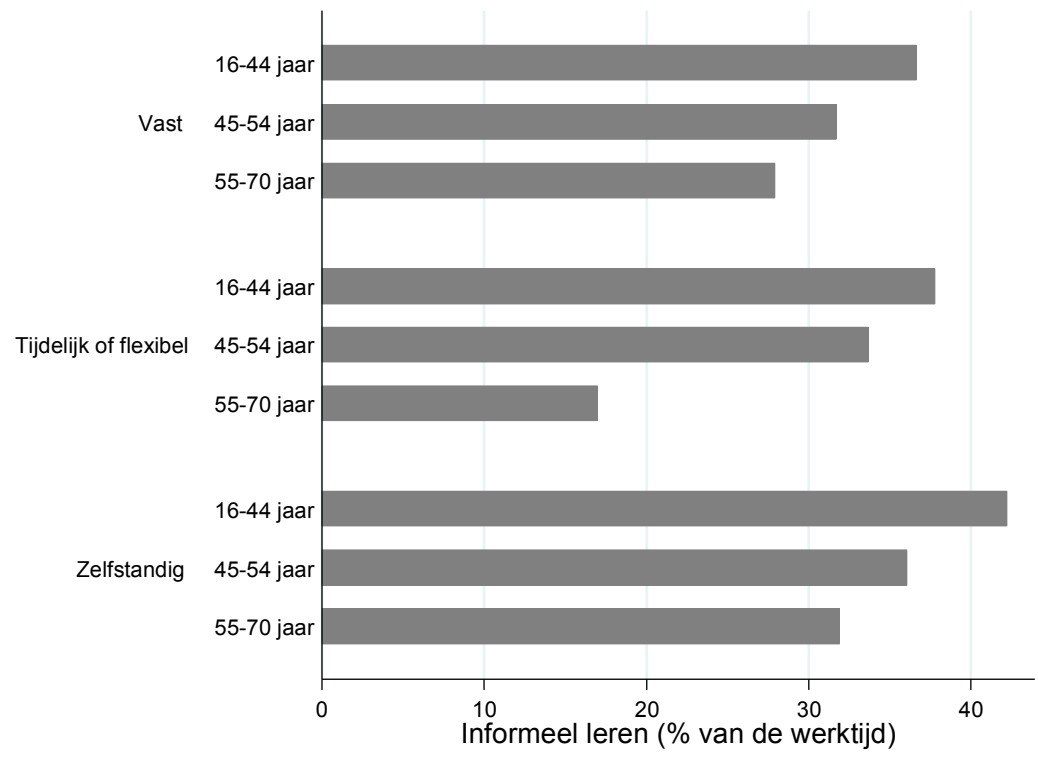




\subsection{Leren, motivatie en HR-beleid}

In de ROA Levenslang Leren Enquête 2013 is gevraagd naar de mate waarin technologische en organisatorische veranderingen zich voordoen op het werk (op een schaal van I 'geen of vrijwel geen veranderingen' tot 5 'zeer grote veranderingen'). Tabel 3.4 laat zien dat er geen verschil is naar leeftijd als het gaat om de mate van organisatorische veranderingen die de inhoud van het werk veranderen. 55-plussers geven daarentegen significant minder vaak aan (zeer) grote technologische ontwikkelingen op het werk mee te maken die de inhoud van het werk veranderen. Dit suggereert dat oudere werknemers minder vaak werkzaam zijn in een technologisch geavanceerde werkomgeving. Ook blijkt dat het

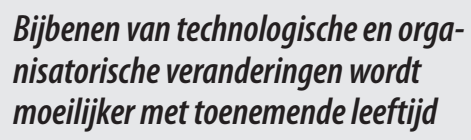
percentage werkenden dat de ontwikkelingen goed of zeer goed kan bijbenen afneemt met het oplopen van de leeftijd. Dit verschil is significant ook nadat gecontroleerd wordt voor opleiding, geslacht en bedrijfssector. Dit laat zien dat het, met het stijgen van de leeftijd, voor een grote groep werkenden moeilijker wordt om mee te komen met deze veranderingen.

Tabel 3.4

Technologische en organisatorische veranderingen op het werk naar leeftijd, werkenden, 2013

\begin{tabular}{|c|c|c|c|}
\hline & $\begin{array}{c}16-44 \text { jaar } \\
\%\end{array}$ & $\begin{array}{c}45-54 \text { jaar } \\
\%\end{array}$ & $\begin{array}{c}55-70 \text { jaar } \\
\%\end{array}$ \\
\hline (Zeer) grote technologische ontwikkelingen die inhoud werk veranderen & 23 & 17 & 17 \\
\hline Kan de ontwikkelingen (zeer) goed bijbenen & 61 & 53 & 47 \\
\hline (Zeer) grote organisatorische ontwikkelingen die inhoud werk veranderen & 31 & 28 & 32 \\
\hline Kan de ontwikkelingen (zeer) goed bijbenen & 61 & 53 & 44 \\
\hline
\end{tabular}

Technologische en organisatorische ontwikkelingen op het werk kunnen bepalend zijn voor de deelname aan scholing door werkenden. Daarnaast kan de scholingsparticipatie gerelateerd zijn aan iemands intrinsieke motivatie of risicohouding of het door de werkgever gevoerde HR-beleid. ${ }^{30}$ Tabel 3.5 laat de uitkomsten zien van econometrische analyses naar deze determinanten van de deelname aan scholing. Medewerkers met een grotere intrinsieke motivatie blijken veel vaker een cursus of training te volgen (zie ook Theranou 200I). Onder I6-44 jarigen gaat een één standaarddeviatie hogere motivatie gepaard met een $17 \%$-punt hogere scholingsdeelname. Onder 55 -plussers is dit zelfs $19 \%$-punt.

30. Hoe deze variabelen gemeten zijn wordt toegelicht in bijlage D. 
Technologische ontwikkelingen op het werk zijn niet gerelateerd aan de scholingsdeelname. Bij de 16-44 jarigen hangen organisatorische veranderingen op het werk daarentegen wel positief en significant samen met de deelname aan formele scholing. Bij de oudere leeftijdsgroepen is dat niet meer het geval. De intensiteit van het gevoerde HR-beleid (gemeten aan de hand van negen aspecten van het HR-beleid) is positief gerelateerd aan de

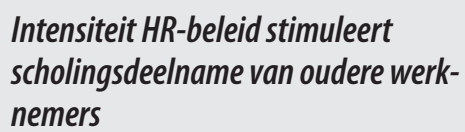

Tabel 3.5

Econometrische analyse voor deelname aan formeel leren (OLS coëfficiënten), 2013¹)

\begin{tabular}{lccc} 
& $16-44$ jaar & $45-54$ jaar & $55-70$ jaar \\
Intrinsieke motivatie & $17,017^{* * *}$ & $14,197^{* * *}$ & $22,107^{* * *}$ \\
\hline Risicoattitude & 3,105 & 5,880 & 4,653 \\
\hline Technologische ontwikkelingen die inhoud werk veranderen & $-1,021$ & 1,660 & 3,349 \\
\hline Organisatorische ontwikkelingen die inhoud werk veranderen & $3,994^{*}$ & 0,863 & 3,451 \\
\hline Intensiteit HR beleid & $4,404^{* * *}$ & $7,046^{* * *}$ & $4,844^{*}$ \\
Adjusted-R-kwadraat & 0,104 & 0,130 & 0,172 \\
N & 494 & 233 & 279 \\
* p<O.10 ** p<0.05 *** p<0.01 & & \\
1) Controlevariabelen: geslacht, opleidingsniveau, leeftijd, soort contract. Uitkomsten van Linear \\
Probability Model.
\end{tabular}

Tabel 3.6 laat vergelijkbare analyses zien voor het informeel leren tijdens het werk. Iemands risicoattitude hangt significant en positief samen met de mate waarin men informeel leert op het werk: mensen die meer risicobereid zijn leren meer. Deze relatie is echter niet significant voor 45-55 jarigen. Ten slotte blijkt de intensiteit van het HR-beleid voor alle leeftijdsgroepen het informeel leren tijdens het werk significant te vergroten. Bij de 45-plussers blijken degenen met een hogere intrinsieke motivatie tijdens hun werk meer informeel te leren. Bij de I6-44 jarigen is dat niet het geval. De relatie tussen iemands intrinsieke motivatie en informeel leren is overigens twee keer sterker voor 55-plussers dan voor 45-54 jarigen.

3I. Montizaan et al. (20I4) laten zien dat in bedrijven met een op ouderen gericht scholingsbeleid werknemers op een latere leeftijd met pensioen verwachten te gaan. 
HOOFDSTUK 3

Tabel 3.6

Econometrische analyse voor tijd besteed aan informeel leren (OLS coëfficiënten), 2013'1)

\begin{tabular}{lccc} 
& $16-44$ jaar & $45-54$ jaar & $55-70$ jaar \\
\hline Intrinsieke motivatie & $-0,671$ & $5,045^{*}$ & $9,423^{* * *}$ \\
\hline Risicoattitude & $2,568^{*}$ & 3,244 & $3,268^{*}$ \\
\hline Technologische ontwikkelingen die inhoud werk veranderen & $-0,237$ & $-0,168$ & $-1,988$ \\
\hline Organisatorische ontwikkelingen die inhoud werk veranderen & 2,266 & 3,097 & 0,587 \\
\hline Intensiteit HR beleid & $3,460^{* * *}$ & 1,720 & 1,078 \\
\hline Adjusted-R-kwadraat & 0,032 & 0,067 & 0,088 \\
\hline N & 494 & 233 & 279
\end{tabular}

${ }^{*} \mathrm{p}<0.10{ }^{* *} \mathrm{p}<0.05{ }^{* * *} \mathrm{p}<0.01$

1) Controle variabelen: geslacht, opleidingsniveau, leeftijd, soort contract 


\section{Literatuur}

Arrow, K. (1962), The Economic Implications of Learning by Doing, Review of Economic Studies, 29(3): 55-73.

Arts, K. \& Otten, F. (2014), Pensioenleeftijd werknemers verder gestegen tot bijna 64 jaar, CBS Webmagzine.

Autor, D. (2001), Why do temporary help firms provide free general skills training?, Quarterly Journal of Economics, 116(4): 1409-1448.

Borghans, L., Golsteyn, B., de Grip, A. (2006), Meer werken is meer leren. Determinanten van kennisontwikkeling, 's-Hertogenbosch: CINOP.

Borghans, L., Golsteyn, B., de Grip, A. (2007), Werkend leren, Economische Statistische Berichten, jaargang 92: 260-263.

Borghans, L., Golsteyn, B., de Grip, A. (2008a), Betekenis (in)formeel leren voor kennisontwikkeling van de beroepsbevolking, In: C. Doets, W. van Esch, A. Westerhuis (eds), Een brede verkenning van een leven lang leren, CINOP, 's-Hertogenbosch (157-172).

Borghans L., Fouarge D., de Grip A. (2011). Een leven lang leren in Nederland, ROA-R-2011/5, Maastricht: ROA.

Borghans, L., Golsteyn, B., de Grip, A., Nelen, A. (2009), De betekenis van het leren op het werk, Utrecht: ecbo.

Di Mauro, C., Musumeci, R. (2011), Linking risk aversion and type of employment, The Journal of Socio-Economics, 40(5): 490-495.

Dohmen, T., Falk, A., Huffman, D., Sunde, U., Schupp, J., Wagner, G. (2011), Individual risk attitudes: measurement, determinants and behavioral consequences, Journal of the European Economic Association, 9(3): 522-550.

Ekelund, J., Johansson, E., Järvelin, M.-R., Lichtermann, D. (2005), Self-employment and risk aversion evidence from psychological test data, Labour Economics, 12(5): 649-659. 
Euwals, R., van Vuuren, D. \& Wolthoff, R. (2010), Early retirement behaviour in the Netherlands: Evidence from a policy reform, De Economist, 158, 209-236.

Fouarge, D. (2010), Bereidheid tot scholing, ESB, 95(4587): 369.

Fouarge, D. (2011), Kennisontwikkeling van oudere werkenden, ESB, 96(4614 \& 4615): 439.

Fouarge, D. (2012), Nooit op training of cursus, ESB, 97(4644): 573.

Fouarge, D., de Grip, A. de (2014), Gaan 50-plussers meer investeren in hun scholing? Tilburg: Netspar NEA paper 54.

Fouarge, D., de Grip, A. (2011), Depreciatie van menselijk kapitaal, Maastricht: ROA rapport (ROA-R-2011/1).

Fouarge, D., Schils, T., de Grip, A. (2010a), Prikkels voor postinitiële scholing voor laagopgeleiden, 's-Hertogenbosch: ecbo.

Fouarge, D., Schils, T., de Grip, A. (2010b), Postinitiële scholing van laagopgeleiden in Nederland: de rol van economische prikkels en HRM, Over. Werk Tijdschrift van het Steunpunt WSE, 20(2): 67-73.

Fouarge, D., de Grip, A., Smits, W., De Vries, R. (2010), Flexible contracts and human capital investments, De Economist, 160: 177-195.

Fouarge, D., Schils, T., de Grip, A. (2013), Why do low-educated workers invest less in further training? Applied Economics, 45(18): 2587-260.

Fouarge, D., de Grip, A. (2012), Postinitieel leren: deelname en rendement, Maastricht: ROAPP-2012/1.

Grip, A., de (2000), Van tweedekansonderwijs naar een leven lang leren, De veranderende betekenis van post-initiële scholing, inaugurele rede, Universiteit Maastricht.

Grip, A., de, Fouarge, D. \& Montizaan, R. (2013), How sensitive are individual retirement expectations to raising the retirement age?, De Economist, 161(3), 225-251.

Grip, A. de, van Loo, J. (2002), The Economics of Skills Obsolescence: A Review, in: A. de Grip, J. van Loo \& K. Mayhew (Eds), The Economics of Skills Obsolescence, Research in Labor Economics, 21, JAI Press, 1-26.

Grip, A. de \& Sauermann, J. (2013), The effect of training on productivity: The transfer of onthe-job training from the perspective of economics, Educational Research Review, 8: 28-36. 
Heckman, J. (2000), Policies to foster human capital, Research in Economics, 54: 3-56.

Loog, B., Smits, W. \& de Vries, R. (2014), Arbeidsmarktdynamiek in Nederland: 2003-2013, Tijdschrift voor Arbeidsvraagstukken, 30(1): 27-39.

Maximiano, S. (2011), Two to tango: the determinants of workers'and firms' willingness to participate in job-related training, Mimeo, Purdue University.

Montizaan, R., Cörvers, F. \& de Grip, A. (2010), The effects of pension rights and retirement age on training participation: Evidence from a natural experiment, Labour Economics, 17: 240-247.

Montizaan, R., de Grip, A. \& Fouarge, D. (2014), Training policies and retirement expectations, Mimeo.

Nelen, A., de Grip, A. (2008), Het menselijk kapitaal van deeltijders, ESB, 93(4546): 653-654.

Nelen, A., de Grip, A. (2009), Why do part-time workers invest less in human capital than full-timers?, Labour, 23: 61-83.

ROA (2013), De arbeidsmarkt naar opleiding en beroep tot 2018, Maastricht: ROA-R-2013/11.

Tharenou, P. (2001), The relationship of training motivation to participation in training and development, Journal of Occupational and Organizational Psychology, 74(5), 599-621.

Zijl, M. (2006), Economic and social consequences of temporary employment, Academisch proefschrift, Tinbergen Institute Research Series, Amsterdam.

Zwick, T. (2011), Why training older employees is less effective, Mannheim: ZEW Discussion Papers, No. 11-046. 



\section{Bijlage A: ROA Levenslang Leren Enquête}

\section{Samenstelling}

De ROA Levenslang Leren Enquête werd gehouden onder de leden van het CentERpanel in de maanden oktober/november van 2004, 2007 en 20I0, en de maand december 2013. In totaal gaat het om 2.376 respondenten in 2004 (waarvan 2.039 jonger dan 67 jaar), I.776 respondenten in 2007 (waarvan I.456 jonger dan 67 jaar), I.974 respondenten in 2010 (waarvan I.547 jonger dan 67 jaar) en 1.992 respondenten in 2013 (waarvan I.488 jonger dan 67 jaar). Gelet op de focus op flexwerkers in hoofdstuk 2 van dit rapport is in 2013 een selectieve groep van 535 respondenten uit het LISS panel geënquêteerd. Het gaat hier voornamelijk om personen met een flexibele aanstelling en zelfstandigen..$^{32}$ De samenstelling naar geslacht, leeftijd, opleidingsniveau en arbeidsmarkt status is weergegeven in tabel A.I. Voor de beschrijvende analyses in dit rapport zijn de data gewogen naar geslacht, leeftijd en opleidingsniveau. De 20 o en 2013 data zijn beschikbaar via DANS (http://www.dans.knaw.nl/).

\section{Kernvariabelen}

De in dit rapport gepresenteerde data zijn uniek in de zin dat ze o.a. gedetailleerd ingaan op de cursusparticipatie, het informeel leren tijdens het werk en iemands kennisontwikkeling op een wijze die het mogelijk maakt om de bevindingen in de loop der jaren te vergelijken. Van een aantal kernvariabelen wordt in tabel A.2 aangeven hoe deze gemeten zijn.

\section{Selectie van waarnemingen}

De analyses in hoofdstukken I en 2 zijn gebaseerd op respondenten tussen de I6 en 66 jaar. Hoofdstuk 3 is gebaseerd op respondenten tot en met 70 jaar. Hoofdstuk 2 maakt gebruik van de aanvulling van cases uit het LISS panel.

\section{Eerdere publicaties op basis van de ROA Levenslang Leren Enquête}

Borghans, L., Golsteyn, B., de Grip, A. (2006), Meer werken is meer leren, Determinanten van kennisontwikkeling, 's-Hertogenbosch: CINOP.

32. De LISS data is herwogen naar de verdeling van werkenden naar soort contract (zoals gedefinieerd in hoofdstuk 2) in het CentERpanel. 
Borghans, L., Golsteyn, B., de Grip, A. (2007), Werkend leren, Economische Statistische Berichten, jaargang 92: 260-263.

Borghans, L., Golsteyn, B., de Grip, A. (2008a), Betekenis (in)formeel leren voor kennisontwikkeling van de beroepsbevolking, In: C. Doets, W. van Esch, A. Westerhuis (eds), Een brede verkenning van een leven lang leren, CINOP, 's-Hertogenbosch (157-172).

Borghans, L., Fouarge, D., de Grip, A. (2011), Een leven lang leren in Nederland, ROAR-2011/5, Maastricht: ROA.

Borghans, L., Golsteyn, B., de Grip, A., Nelen, A. (2009), De betekenis van het leren op het werk, Utrecht: ecbo.

Fouarge, D. (2010), Bereidheid tot scholing, ESB, 95(4587): 369.

Fouarge, D. (2011), Kennisontwikkeling van oudere werkenden, ESB, 96(4614 \& 4615): 439.

Fouarge, D. (2012), Nooit op training of cursus, ESB, 97(4644): 573.

Fouarge, D., de Grip, A. (2014), Gaan 50-plussers meer investeren in hun scholing? Tilburg: Netspar NEA paper 54.

Fouarge, D., de Grip, A. (2011), Depreciatie van menselijk kapitaal, Maastricht: ROA rapport (ROA-R-2011/1).

Fouarge, D., Schils, T., de Grip, A. (2010a), Prikkels voor postinitiële scholing voor laagopgeleiden. 's-Hertogenbosch: ecbo.

Fouarge, D., Schils, T., de Grip, A. (2010b), Postinitiële scholing van laagopgeleiden in Nederland: de rol van economische prikkels en HRM, Over.Werk Tijdschrift van het Steunpunt WSE, 20(2): 67-73.

Fouarge, D., Schils, T., de Grip, A. (2013), Why do low-educated workers invest less in further training? Applied Economics, 45(18): 2587-260.

Fouarge, D., de Grip, A. (2012), Postinitieel leren: deelname en rendement. Maastricht: ROAPP-2012/1.

Grip, A., de \& Sauermann, J. (2013), The effect of training on productivity: The transfer of onthe-job training from the perspective of economics, Educational Research Review, 8: 28-36.

Nelen, A., de Grip, A. (2008), Het menselijk kapitaal van deeltijders, ESB, 93(4546): 653-654.

Nelen, A., de Grip, A. (2009), Why do part-time workers invest less in human capital than full-timers?, Labour, 23: 61-83. 
Tabel A.1

Samenstelling van de steekproef

\begin{tabular}{lcccc} 
& 2004 & 2007 & 2010 & $2^{2013^{11}}$ \\
\hline Totaal & 2.376 & 1.776 & 1.974 & 1.992 \\
Geslacht & & & & \\
man & 1.244 & 938 & 1.055 & 1.040 \\
vrouw & 1.132 & 838 & 919 & 952
\end{tabular}

$\begin{array}{lrrrr}\text { Leeftijd } & & & \\ \text { 16-24 jaar } & 159 & 90 & 82 & 61 \\ 25-34 \text { jaar } & 402 & 249 & 155 & 261 \\ 35-44 \text { jaar } & 473 & 305 & 334 & 304 \\ 45-54 \text { jaar } & 528 & 385 & 373 & 331 \\ 55-64 \text { jaar } & 406 & 375 & 515 & 450 \\ 65+\text { jaar } & 408 & 372 & 515 & 603\end{array}$

$\begin{array}{lrrrr}\begin{array}{l}\text { (pleidingsniveau }{ }^{2)} \\ \text { basisonderwijs }\end{array} & 139 & 94 & 104 & 80 \\ \text { vmbo } & 633 & 492 & 534 & 474 \\ \text { havo/vwo } & 311 & 229 & 230 & 224 \\ \text { mbo } & 463 & 345 & 330 & 335 \\ \text { hbo } & 564 & 415 & 518 & 567 \\ \text { wo } & 263 & 197 & 254 & 311\end{array}$

\section{Arbeidsmarktstatus}

werknemer in loondienst

zelfstandige of meewerkend gezinslid

1.197

$900 \quad 916$

werkzoekend

arbeidsongeschikt

52

28

40

huisvrouw/huisman

312

225

198

student of scholier

141

76

64

(vroeg)gepensioneerd

406

381

vrijwilliger of iets anders

68

521

52

$521 \quad 548$

46

54

84

1) Aantallen exclusief de aanvulling uit het LISS panel.

2) In het rapport wordt ook wel verwezen naar laagopgeleiden (basisonderwijs of vmbo), middelbaar opgeleiden (mbo of havo/vwo) en hoogopgeleiden (hbo of wo). 


\section{Tabel A.2}

Meting van een aantal kernvariabelen in de ROA Levenslang Leren Enquête

\begin{tabular}{ll} 
Variabele & Vraag \\
$\begin{array}{l}\text { Deelname aan cursussen en } \\
\text { trainingen }\end{array}$ & $\begin{array}{l}\text { Hoeveel cursussen en/of trainingen hebt u de afgelopen twee jaar afgerond? } \\
\text { Laat pure hobby-cursussen (bridge, schilderen) buiten beschouwing. Cursussen die u als } \\
\text { hobby ziet, maar voor anderen nuttig kunnen zijn voor het werk tellen wel mee. }\end{array}$ \\
\hline Informeel leren & Hoeveel procent van de werktijd besteedt u aan taken waarvan u kunt leren? \\
\hline Kennisontwikkeling & $\begin{array}{l}\text { Stelt u zich voor welke kennis en vaardigheden nodig zijn voor uw werk om in uw ogen } \\
\text { optimaal te kunnen functioneren. Als dit ideaal gelijk is aan 100, hoe hoog schat u dan uw } \\
\text { vaardigheden in: } \\
\text { twee jaar geleden? } \\
\text { op dit moment? } \\
\text { De kennisontwikkeling wordt gemeten als het verschil tussen de twee antwoorden. }\end{array}$
\end{tabular}




\section{Bijlage B: Formeel, informeel leren en zelfstudie naar bedrijfssector}

Tabel B.1

Formeel, informeel leren en zelfstudie naar bedrijfssector")

\begin{tabular}{lccc} 
& Cursus/training & Informeel leren & Zelfstudie \\
\hline Industrie en landbouw & 47 & 29 & 34 \\
\hline Bouw, transport & 52 & 33 & 27 \\
\hline Handel, horeca & 31 & 32 & 29 \\
\hline Financiële en zakelijke dienstverlening & 57 & 30 & 40 \\
\hline Openbaar bestuur & 54 & 33 & 34 \\
\hline Onderwijs & 60 & 35 & 62 \\
\hline $\begin{array}{l}\text { Zorg en welzijn } \\
\text { Cultuur, sport, recreatie }\end{array}$ & 54 & 46 & 50 \\
$\begin{array}{l}\text { 1) Percentage deelname voor cursusdeelname en zelfstudie, en percentage van de werktijd voor } \\
\text { informeel leren }\end{array}$ & 38 & 22 & 38 \\
\hline
\end{tabular}





\section{Bijlage C: Kosten van scholing en initiatief voor scholing naar contractvorm en opleidingsniveau}

Tabel C.1

Wie betaalt de scholing en wie neemt het initiatief?, naar contractvorm en opleidingsniveau, 2013

\begin{tabular}{|c|c|c|c|c|c|c|}
\hline & \multicolumn{3}{|c|}{ Wie betaalde de kosten van scholing? } & \multicolumn{3}{|c|}{ Wie nam initiatief tot scholing? } \\
\hline & $\begin{array}{c}\text { Zelf } \\
\%\end{array}$ & $\begin{array}{c}\text { Werkgever } \\
\%\end{array}$ & $\begin{array}{c}\text { Anders } \\
\%\end{array}$ & $\begin{array}{l}\text { Zelf } \\
\%\end{array}$ & $\begin{array}{c}\text { Werkgever } \\
\%\end{array}$ & $\begin{array}{l}\text { Beiden } \\
\%\end{array}$ \\
\hline \multicolumn{7}{|l|}{ Vast } \\
\hline Laag & 15 & 85 & 0 & 24 & 53 & 23 \\
\hline Middelbaar & 6 & 93 & 1 & 28 & 41 & 31 \\
\hline Hoog & 5 & 90 & 5 & 44 & 35 & 21 \\
\hline \multicolumn{7}{|l|}{ Flex ${ }^{1)}$} \\
\hline Laag & 17 & 57 & 26 & 32 & 40 & 28 \\
\hline Middelbaar & 22 & 74 & 4 & 31 & 42 & 27 \\
\hline Hoog & 24 & 70 & 6 & 43 & 23 & 34 \\
\hline
\end{tabular}





\section{Bijlage D: Meting van motivatie, risico attitude en $\mathrm{HR}$ beleid}

Intrinsiek motivatie om te leren is in de 2010 en 2013 peiling van de ROA Levenslang Leren Enquête gemeten aan de hand van vijf geselecteerde items uit de schaal van Theranou (200I) waarop respondenten op een schaal van I tot 5 konden aangeven in welke mate de uitspraak op hen van toepassing is. Voorbeelden zijn: "Ik zou graag mijn vaardigheden willen verbeteren", en "Ik ben bereid om me in te spannen op een cursus om mijn kennis en vaardigheden te verbeteren".

Risicoattitude wordt gemeten aan de hand van de door Dohmen et al. (20II) gevalideerde vraag: "Hoe ziet u uzelf? Bent $\mathrm{u}$ in het algemeen iemand die bereid is om risico's te nemen of probeert u risico's te vermijden?". Respondenten konden antwoorden op een schaal van o "helemaal niet bereid om risico's te nemen" tot Io "zeer bereid om risico's te nemen”.

Het HR beleid wordt gemeten aan de hand van 9 vragen over de wijze waarop het bedrijf of de organisatie aandacht besteed aan het functioneren van werknemers en/ of loopbaanontwikkeling. Bijvoorbeeld of er functionerings- en/of beoordelingsgesprekken zijn, een loopbaanplan, coaching, ...

Deze variabelen zijn gestandaardiseerd met gemiddelde o en standaarddeviatie I. 
